\title{
Carbon and nitrogen mineralization in sediments of the Bangrong mangrove area, Phuket, Thailand
}

\author{
Erik Kristensen ${ }^{1, *}$, Frede Ø. Andersen ${ }^{1}$, Nikolaj Holmboe ${ }^{1}$, Marianne Holmer ${ }^{1}$, \\ Nalinee Thongtham ${ }^{2}$
}

\author{
${ }^{1}$ Institute of Biology, Odense University, SDU, 5230 Odense M, Denmark \\ ${ }^{2}$ Phuket Marine Biological Center, PO Box 60, Phuket 83000, Thailand
}

\begin{abstract}
Carbon and nitrogen mineralization were determined along a transect from a mangrove forest to a seagrass meadow in the Bangrong area, Phuket Island, Thailand. Vertical sediment profiles of carbon oxidation were measured as sulfate reduction rates (SRR) using the ${ }^{35} \mathrm{~S}$ technique and by monitoring net $\mathrm{TCO}_{2}$ and DOC production and Fe(III) reduction using anaerobic sediment incubations ('jar' technique). Nitrogen transformations were measured simultaneously as net $\mathrm{NH}_{4}{ }^{+}$and DON production. In addition, total benthic metabolism and net nitrogen exchange were determined as fluxes of $\mathrm{O}_{2}, \mathrm{TCO}_{2}, \mathrm{DOC}$, and DIN $\left(\mathrm{NO}_{3}{ }^{-}\right.$and $\left.\mathrm{NH}_{4}{ }^{+}\right)$across the sediment-water interface. Rates of carbon and nitrogen transformations in this vascular-plant (high $\mathrm{C}: \mathrm{N}$ )-dominated area were low compared with areas fuelled by detritus of marine origin (low C:N). It appears that the high content of structural biopolymers (e.g. lignocelluloses) hampers microbial activity. Suboxic respiration with Fe(III) as electron acceptor accounted for 70 to $80 \%$ of the total carbon oxidation in the rooted mangrove forest sediment, whereas SRR and aerobic respiration were responsible for about 20 and $<6 \%$, respectively. The role of SRR decreased to about $10 \%$ and aerobic respiration increased to $45-65 \%$ in an adjacent bioturbated mudflat, while Fe(III) respiration decreased to $30-40 \%$. At the sand flat and seagrass meadow outside the mangrove forest, Fe(III) respiration only accounted for 15 and $~ 0 \%$, respectively, whereas SRR was responsible for 20 to $45 \%$ of the total carbon oxidation. However, the most important electron acceptor in the area outside was oxygen (55 to $75 \%$ ). The shift in dominance of electron acceptors along the transect is primarily related to the presence of roots and infauna, but the sediment composition (e.g. grain size, organic content and iron content) is believed to be an important co-factor. The net production of ammonium in the sediment was not balanced by fluxes of DIN across the sediment-water interface. The missing nitrogen was assigned to a rapid and efficient bacterial ammonium assimilation at the sediment surface as indicated by ammonium turnover times of about $1 \mathrm{~d}$.
\end{abstract}

KEY WORDS: Mangrove forest · Seagrass $\cdot$ Carbon $\cdot$ Nitrogen $\cdot$ Mineralization $\cdot$ Sulfate reduction Fe(III) reduction $\cdot$ Benthic metabolism

- Resale or republication not permitted without written consent of the publisher

\section{INTRODUCTION}

Most sheltered coasts and river deltas in the tropics are lined with mangrove forests (Duke 1992). The salttolerant mangrove trees develop best in a quiescent physical environment, where low wave energy and shelter facilitate accretion of soft and fine-grained sediment that enables the trees to establish roots deep into

*E-mail: ebk@biology.ou.dk the sediment. Many mangrove forests are replaced by non-vegetated intertidal mudflats or sand flats at the seaward edge, which gradually transform into subtidal tropical seagrass meadows. Seagrasses flourish especially in soft sediment at and below the intertidal zone on sheltered coasts (Alongi 1997).

Organic matter produced or deposited on the sediment surface in mangrove forests and seagrass meadows supports aerobic and anaerobic detritus food chains. Studies on benthic infauna in tropical man- 
grove and seagrass environments have shown that densities are generally low compared with other marine habitats (Alongi \& Sasekumar 1992). The infaunal density and diversity is particularly low within the mangrove forest, where burrowing crabs are the dominating faunal feature. These may, however, handle and consume a considerable fraction of the litter fall (Robertson 1986). Highest faunal densities are generally found on adjacent mudflats, where large populations of epibenthic mollusks graze on microphytobenthos. Tropical seagrass meadows, on the other hand, are characterized by highly diverse, but not very abundant infauna (Alongi 1997).

Aerobic microbial decomposition of organic matter is usually more rapid than the rate of oxygen diffusion into surface sediments, and oxygen quickly becomes limiting. Anaerobic bacteria below the upper few millimeters of sediment therefore carry out most decomposition, except where animal burrows and plant roots channel oxygen to deeper sediment layers (Andersen \& Kristensen 1988, Aller 1994). Anaerobic decomposition in marine sediments is performed by a wide variety of bacterial types utilizing a number of electron acceptors (e.g. nitrate, oxidized iron and manganese, and sulfate) to oxidize carbon.

For some time is was believed that aerobic respiration and sulfate reduction each account for about half of the total carbon oxidation in all continental shelf sediments with negligible suboxic respiration using nitrate and metal oxides (Fe and Mn) as electron acceptors (Jørgensen 1983). However, a number of recent studies have revealed that the contribution of sulfate reduction varies with a number of factors such as season, benthic community activity and physical transport conditions. Sulfate reduction has been found to be responsible for up to $100 \%$ of the total benthic metabolism in highly productive and undisturbed coastal environments (Mackin \& Swider 1989), whereas values lower than $10 \%$ have been found in less productive (deeper continental shelf and slope sediments; Canfield et al. 1993) and disturbed (currents, bioturbation and rooted plants; Kristensen et al. 1994, Banta et al. 1999) sediments. Suboxic respiration is usually of limited importance in coastal marine sediments (Aller 1994, Thamdrup et al. 1994, Slomp et al. 1997). In some deeper continental shelf sediments, however, respiration with metal oxides may be responsible for more than $50 \%$ of the total carbon oxidation (Thamdrup 2000). The rate of diagenesis by each respiration pathway in tropical mangrove and seagrass sediments is just beginning to be understood. It was earlier thought that aerobic decomposition is much more important than anaerobic decay in mangrove sediments. More recently, it was shown that this is not always true, and that sulfate reduction may be an important electron ac- ceptor in organic-rich deposits typical of mangrove forests (Kristensen et al. 1994, Alongi et al. 1998).

Another feature of mangrove forests and tropical seagrass meadows is the very low levels of dissolved and particulate nutrients in the sediment and overlying water, and the forests generally appear to be $\mathrm{N}$ or $\mathrm{P}$ limited (Boto \& Wellington 1983). As a consequence, they possess a high capacity for retaining and recycling nutrients by several mechanisms that reduce loss (Twilley et al. 1986). The general characteristics of mangrove sediment with respect to inorganic nitrogen are low concentrations, low release to (or even uptake from) the tidal water, low rates of net transformation processes, and efficient microbial assimilation.

The purpose of this study was to determine the vertical distribution of carbon and nitrogen mineralization in sediments along a mangrove forest-seagrass meadow transition zone. Simultaneous measurements of carbon mineralization, iron oxide reduction, sulfate reduction and fluxes of DIC across the sediment-water interface enabled us to estimate the relative contribution of the dominating electron acceptors for the total carbon oxidation in the sediments. Nitrogen dynamics were evaluated by relating vertical profiles of net nitrogen mineralization with fluxes across the sediment-water interface.

\section{MATERIALS AND METHODS}

Study site. The study was conducted in the Bangrong mangrove forest $\left(8^{\circ} 03^{\prime} \mathrm{N}, 98^{\circ} 25^{\prime} \mathrm{E}\right)$ on the northeast coast of Phuket Island, Thailand (Fig. 1). The

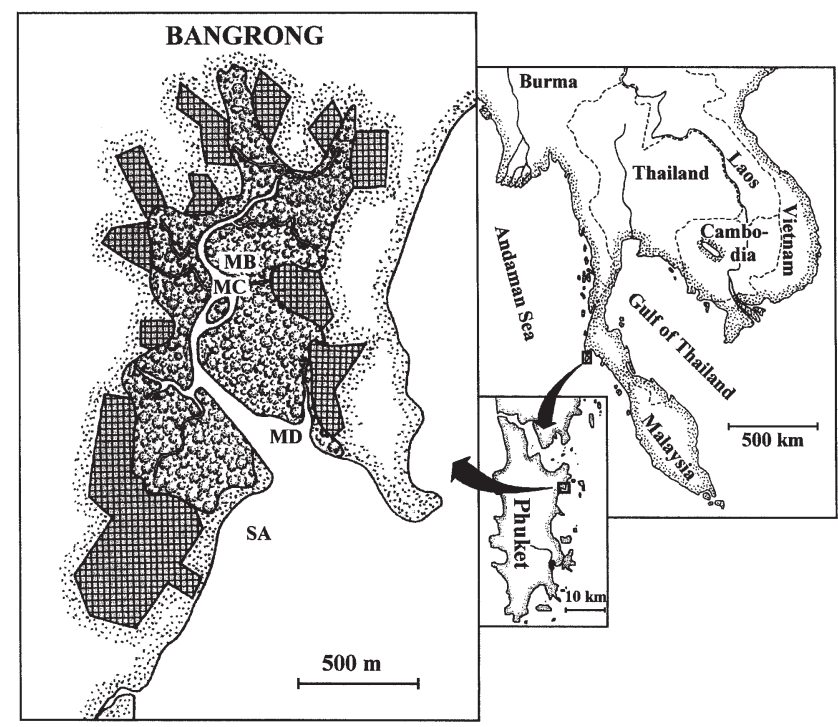

Fig. 1. Map of the Bangrong mangrove forest with Stns MB, $\mathrm{MC}, \mathrm{MD}$ and SA indicated 
climate is monsoonal with a dry season from November to April and a wet season from May to October. Annual precipitation is about $2300 \mathrm{~mm}$ and the average temperature is $28^{\circ} \mathrm{C}$. The forest is a tide-dominated fringe mangrove setting which stretches as a ca $1 \mathrm{~km}$ wide lagoon about $2 \mathrm{~km}$ inland. There are no major freshwater discharges to the forest (except during heavy rains) and tidal water exchange with the ocean (average salinity of $35 \%$ ) occurs through 1 main channel fed by smaller creeks along the length axis of the forest. Tidal range in the area is about $2.5 \mathrm{~m}$. The vegetation within the forest is dominated by the trees Rhizophora apiculata, R. mucronata and Ceriops Tagal. The forest has suffered from extensive cuttings during the last decades and is now surrounded by shrimp farms, which drain into the forest.

Sediment was sampled in January 1996 (dry season), August 1997 (wet season) and May 2000 (transition between dry and wet seasons) at 4 stations along a transect in the Bangrong area (Fig. 1): Stn MB in the midintertidal part of the mangrove forest (flooded about $30 \%$ of the time) between 'prop' roots of Rhizophora mucronata, about $10 \mathrm{~m}$ from the main tidal channel; Stn $\mathrm{MC}$ at a non-vegetated mudflat in the main channel at approximately the same tidal level as the previous station (flooded about $50 \%$ of the time); Stn MD at a nonvegetated low-intertidal mudflat and sand flat about $50 \mathrm{~m}$ outside the forest (flooded about $60 \%$ of the time); and Stn SA in a low-intertidal sandy seagrass (Enhalus acoroides [L. f] Royle) meadow about $500 \mathrm{~m}$ outside the forest (flooded about $95 \%$ of the time).

Jar incubations. Anaerobic carbon and nitrogen mineralization rates were determined at $0-1,2-3,6-8$, and 14-16 cm depth in the sediment. During each sampling occasion, 4 sediment cores $(8 \mathrm{~cm}$ inner diameter [i.d.] and $20 \mathrm{~cm}$ deep) were sampled from each station by hand at low tide using acrylic core tubes. After sectioning of sediment cores into the chosen depth intervals, the 4 slices from each depth interval and station were pooled and mixed thoroughly. The homogeneous sediment mixture ( 200 ml) was immediately transferred into six $20 \mathrm{ml}$ glass scintillation vials (jars), which were capped with no headspace, taped to prevent oxygen intrusion and incubated in the dark at $28^{\circ} \mathrm{C}$. All sediment handling in May 2000 was carried out under $\mathrm{N}_{2}$ atmosphere. Two jars from each depth were sacrificed at 2 (May 2000) to 7 d (January 1996 and August 1997) intervals for determination of porewater $\mathrm{TCO}_{2}, \mathrm{NH}_{4}{ }^{+}, \mathrm{DOC}, \mathrm{DON}$ (January 1996 only) and $\mathrm{Fe}^{2+}$ (May 2000 only) concentrations. Porewater was extracted from the jars by centrifugation at $3000 \mathrm{rpm}(1200 \times g)$ for $15 \mathrm{~min}$. After GF/F filtration, $\mathrm{TCO}_{2}$ was analyzed immediately by the flow injection/diffusion cell technique of Hall \& Aller (1992) and $\mathrm{Fe}^{2+}$ was analyzed spectrophotometrically by the Fer- rozine technique (50 $\mu \mathrm{l}$ sample transferred to $2 \mathrm{ml}$ of $0.02 \%$ Ferrozine in $50 \mathrm{mM}$ HEPES buffer, $\mathrm{pH}=7$ ) (Stookey 1970), while DOC, DON and $\mathrm{NH}_{4}{ }^{+}$subsamples were stored frozen for subsequent analysis. DOC was analyzed on a Shimadzu TOC-5000 Total Organic Carbon Analyzer after acidification with $2 \mathrm{M} \mathrm{HCl}$ $(\mathrm{pH}<3)$ to remove DIC. DON was analyzed on a Dohrmann (DN-1900) Organic Nitrogen Analyzer. The manual salicylate-hypochlorite method of Bower \& Holm-Hansen (1980) was used for $\mathrm{NH}_{4}{ }^{+}$analysis. The $\mathrm{NH}_{4}{ }^{+}$data were corrected for adsorption by the dimensionless ammonium adsorption coefficient $(K)$ reported for these sediments by Holmboe \& Kristensen (2000).

In the May 2000 jar series, the sediment remaining after porewater retrieval was homogenized under $\mathrm{N}_{2}$ atmosphere for iron extraction by a modified version of the $\mathrm{HCl}$ technique of Lovley \& Phillips (1987). Briefly, a 100 to $300 \mathrm{mg}$ subsample was extracted in $5 \mathrm{ml}$ of $0.5 \mathrm{M} \mathrm{HCl}$ for $1 \mathrm{~h}$ on a shaking platform at $20^{\circ} \mathrm{C}$. After centrifugation (1500 rpm [400 × g] for $10 \mathrm{~min}), 50 \mu \mathrm{l}$ of the supernatant was transferred to $2 \mathrm{ml}$ Ferrozine solution for Fe(II) analysis and to $2 \mathrm{ml}$ Ferrozine solution containing the reducing agent hydroxylamine $\left(10 \mathrm{~g} \mathrm{l}^{-1}\right)$ for total-Fe (Fe(II)+Fe(III)) analysis. The reactive amorphous Fe(III) oxide concentration was then operationally defined as the difference between total Fe and Fe(II) (Kostka \& Luther 1994).

Transformation rates in the jars were calculated from a linear fit of concentration changes in the time series of samples.

Sulfate reduction assay. Sulfate reduction was measured by the core injection technique of Jørgensen (1978). Three $20 \mathrm{~cm}$ long cores were sampled (January 1996 and August 1997) from each station using $25 \mathrm{~cm}$ long and $2.6 \mathrm{~cm}$ i.d. core tubes with silicone-filled injection ports. A volume of $10 \mu \mathrm{l}$ carrier-free ${ }^{35} \mathrm{~S}_{-} \mathrm{SO}_{4}{ }^{2-}$ $(111 \mathrm{kBq})$ was injected at $1 \mathrm{~cm}$ intervals to $18 \mathrm{~cm}$ depth and the cores were incubated with dry surface in darkness for 8 to $10 \mathrm{~h}$. Subsequently, each core was sectioned into 1 or $2 \mathrm{~cm}$ segments and fixed in $20 \% \mathrm{ZnAc}$. Samples were stored frozen until distillation by the 1-step procedure of Fossing \& Jørgensen (1989) and radioassayed within 1 mo.

Sediment-water fluxes. For determination of dark fluxes of $\mathrm{O}_{2}$, DIC $\left(\mathrm{CO}_{2}\right)$ and DIN (DIN $=\mathrm{NH}_{4}{ }^{+}, \mathrm{NO}_{2}{ }^{-}$ and $\mathrm{NO}_{3}{ }^{-}$) across the sediment-water interface during inundation, 3 sediment cores $(8 \mathrm{~cm}$ i.d. and $20 \mathrm{~cm}$ deep) were sampled per station during low tide (January 1996 and August 1997). In the laboratory, seawater from the site was carefully added to the still air-exposed, but darkened, cores to a height of about $9 \mathrm{~cm}$ and the cores were then pre-incubated for 3 to $5 \mathrm{~h}$ at in situ temperature. Flux measurements were done by closed-core incubations of 3 to $4 \mathrm{~h}$ duration in darkness. Briefly, the water-filled cores were placed in a 
thermostatted $\left(28\right.$ to $29^{\circ} \mathrm{C}$ ) water tank and supplied with a stirring magnet driven by an external rotating magnet $(60 \mathrm{rpm})$. The water phase in the cores was replaced $1 \mathrm{~h}$ before initiating the incubation. An additional core tube containing only seawater from the site was included for determination of the overlying water contribution. Water samples were taken at the start and end of the incubation, assuming linear concentration change with time. This was occasionally verified by sequential samplings. The sampled water was GF/F filtered and subsamples for $\mathrm{O}_{2}$ and $\mathrm{TCO}_{2}$ were analyzed immediately. $\mathrm{O}_{2}$ was analyzed by the standard Winkler technique (Parsons et al. 1984). $\mathrm{TCO}_{2}$ was analyzed as mentioned above. Subsamples for DOC and DIN measurements were stored frozen and analyzed as mentioned above for DOC and $\mathrm{NH}_{4}{ }^{+} \cdot \mathrm{NO}_{2}{ }^{-}$ and $\mathrm{NO}_{3}{ }^{-}$was analyzed by the standard autoanalyzer method of Armstrong et al. (1967). As $\mathrm{NO}_{2}^{-}$concentrations were very low and constant, this compound was included in the $\mathrm{NO}_{3}{ }^{-}$data presented in this study.

Sediment characteristics. Separate samples of the initial sediment mixture (free of visible roots and rhizomes) were taken for determination of porosity, organic content and solid phase iron (Fe(II) and Fe(III)) content. Porosity was estimated from water loss upon drying of sediment subsamples at $100^{\circ} \mathrm{C}$ and wet density (weight of a known volume). The dried sediments were subsequently used for determination of POC and PON by a Carlo Erba EA1108 CHNS analyzer using the difference-on-ignition method (Kristensen \& Andersen 1987). Sediment subsamples for iron determination were handled and analyzed as described above for jar incubations.

\section{RESULTS}

\section{Sediment properties along the transect}

The sediment changed gradually along the transect from organic-rich silt within the mangrove forest to organic-poor sand in the seagrass bed. Only the upper 1 to $2 \mathrm{~cm}$ of the sediment at Stn MB was devoid of roots; below was a deep root zone of peat-like appearance. There were no visible plant roots at Stns MC and $\mathrm{MD}$, but live and dead seagrass roots were found scattered in the sediment at Stn SA. Only a few burrowing animals were visible at Stns MB, MD and SA. Stn MC, on the other hand, was intensively bioturbated by fiddler crabs (55 ind. $\mathrm{m}^{-2}$; Holmer et al. 1999) and an unknown number of mudskippers. The sediment was composed of grey-brown silt at Stn MB (70\% of particles $<63 \mu \mathrm{m}$, median particle size $50 \mu \mathrm{m}$; E. Kristensen, unpubl.) and Stn MC (50\% of particles $<63 \mu \mathrm{m}$, median particle size $70 \mu \mathrm{m})$, whereas the sediment at
Stn MD was more heterogeneous and consisted of silty-sand (15 to $20 \%$ of particles $<63 \mu \mathrm{m}$, median particle size $200 \mu \mathrm{m}$ ) with a brown-black color and large detritus particles scattered throughout the examined depth interval. The sandy sediment at Stn SA (5 to $10 \%$ of particles $<63 \mu \mathrm{m}$, median particle size $150 \mu \mathrm{m}$ ) had a clearly visible 1 to $2 \mathrm{~cm}$ brown oxidized surface layer overlying a grey-black subsurface sediment. Porosity was highest near the surface at all stations, but decreased from about 0.8 to 0.5 along the transect (Table 1). Likewise, POC and PON content at the surface decreased from 3.7 to $0.5 \mathrm{mmol} \mathrm{g}^{-1}$ dry weight (dw) and 190 to $<5 \mu \mathrm{mol} \mathrm{g}{ }^{-1} \mathrm{dw}$, respectively. Consequently, the POC:PON ratio increased from about 20 to 100 along the transect. While POC generally decreased less than $10 \%$ from the surface to $14-16 \mathrm{~cm}$ depth in the sediment, PON at Stns MB, MC and MD was reduced by about 20 to $40 \%$ within the same depth interval, causing the sedimentary $\mathrm{C}: \mathrm{N}$ ratio to increase with depth in the sediment. PIC (e.g. calcite) content was low at all stations, generally accounting for less than $1 \%$ of the POC content.

Particulate iron content reflected the general sediment characteristics. Highest iron (both Fe(II) and amorphous Fe(III)) contents were observed in the finegrained sediments of Stns $\mathrm{MB}$ and $\mathrm{MC}$, while the sandy sediments of Stns MD and SA contained up to 1 order of magnitude less iron (Table 2). Amorphous Fe(III) accounted for 10 to $30 \%$ of the total $\mathrm{HCl}$ extractable iron content in the upper $8 \mathrm{~cm}$ of the rooted and bioturbated Stns MB and MC. Below this depth, amorphous Fe(III) decreased to less than $3 \%$. At the iron-poor Stns MD and SA, amorphous Fe(III) reached 10 to $20 \%$ of the total $\mathrm{HCl}$ extractable pool only in the upper $\mathrm{cm}$ of the sediment and decreased to trace amounts $(<5 \%$ of the total) deeper down.

\section{Jar rates}

The concentration of the examined porewater solutes and solid phase amorphous Fe(III) generally changed in a linear fashion over the 2 wk (about $350 \mathrm{~h}$ ) incubation period at all stations and sediment depths (Fig. 2). The deviations from linearity observed in a few cases, particularly for DOC and DON, were primarily caused by analytical uncertainties.

Carbon mineralization $\left(\mathrm{CO}_{2}\right.$ production) decreased with depth at all stations (Figs. 3 to 5) and was most pronounced from $0-1$ to $2-3 \mathrm{~cm}$ depth. Surface rates were about twice as high at Stn MC (800 to $1040 \mathrm{nmol}$ $\mathrm{cm}^{-3} \mathrm{~d}^{-1}$ ) than at Stn MB (490 to $520 \mathrm{nmol} \mathrm{cm}{ }^{-3} \mathrm{~d}^{-1}$ ) in January and August, whereas no significant difference was observed in May (868 \pm 190 and $1034 \pm 66 \mathrm{nmol}$ $\mathrm{cm}^{-3} \mathrm{~d}^{-1}$, respectively). Surface rates at Stns MD and 
Table 1. Profiles of porosity, POC and PON and POC:PON ratio in the depth intervals used for the jar incubations. Porosity is given as mean $\pm \mathrm{SD}(\mathrm{n}=3)$. Values for POC and PON are given as mean \pm range of 2 determinations. ud: under detection limit

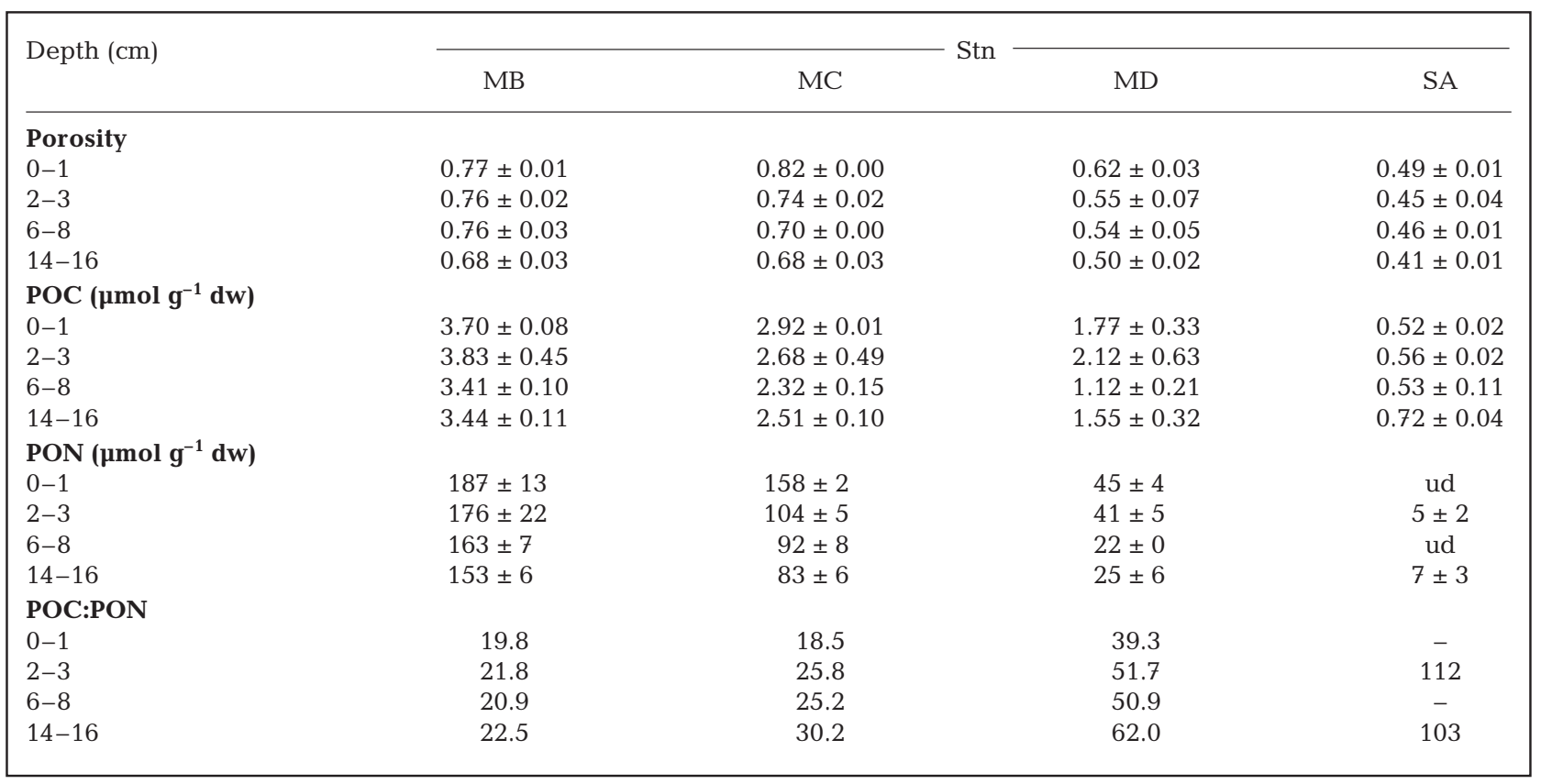

Table 2. Profiles of solid phase iron (Fe(II) and Fe(III)) in the depth intervals used for the jar incubations. Values are given as mean $\pm \mathrm{SD}(\mathrm{n}=3)$

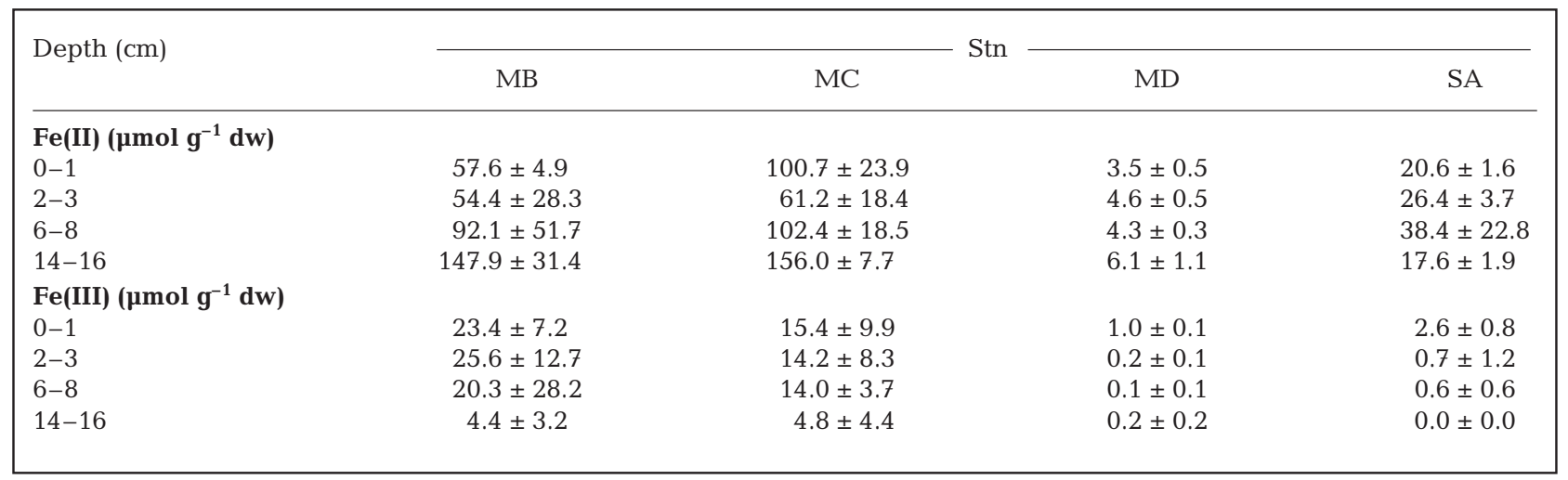

SA were similar, and at a level (180 to $610 \mathrm{nmol} \mathrm{cm}^{-3}$ $\mathrm{d}^{-1}$ ) generally less than half of those observed at Stns $\mathrm{MB}$ and $\mathrm{MC}$. Subsurface rates (within a range of 0 to $660 \mathrm{nmol} \mathrm{cm}^{-3} \mathrm{~d}^{-1}$ ) were generally less than $30 \%$ of the surface rates, except for Stn MB in May and August and Stn SA in January (30 to 60\%). The depth-integrated $\mathrm{CO}_{2}$ production was 1.5 to 5 times higher at Stns $\mathrm{MB}$ and $\mathrm{MC}$ than at Stns MD and SA, with no specific seasonal trends (Table 3 ).

The reduction of $\mathrm{Fe}(\mathrm{III})$ showed no significant change from the surface down to $3 \mathrm{~cm}$ sediment depth at Stns MB, MC, MD. Unfortunately, no rates could be obtained at Stn SA due to low and erratic develop- ments in the jar time series. Highest rates were found

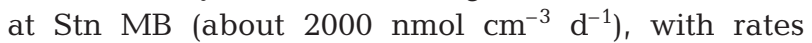
about twice as high as those at Stn MC (750 to 1150 nmol $\mathrm{cm}^{-3} \mathrm{~d}^{-1}$ ) and more than 4 times higher than those at Stn MD (300 to $500 \mathrm{nmol} \mathrm{cm} \mathrm{cm}^{-3} \mathrm{~d}^{-1}$ ). Fe(III) reduction was generally much lower in the deeper sediment layers ( 0 to $300 \mathrm{nmol} \mathrm{cm} \mathrm{cm}^{-3} \mathrm{~d}^{-1}$ ), except for the 6 to $8 \mathrm{~cm}$ layer at Stn MB $\left(800 \mathrm{nmol} \mathrm{cm}^{-3} \mathrm{~d}^{-1}\right)$. By assuming that $\mathrm{Fe}(\mathrm{III})$ reduction is entirely microbial respiration and used in carbon oxidation with a Fe:C stoichiometry of 4:1 (Froelich et al. 1979), the contribution of $\mathrm{Fe}(\mathrm{III})$ respiration to the total $\mathrm{CO}_{2}$ production in jars was assessed. It appears that Fe(III) respi- 

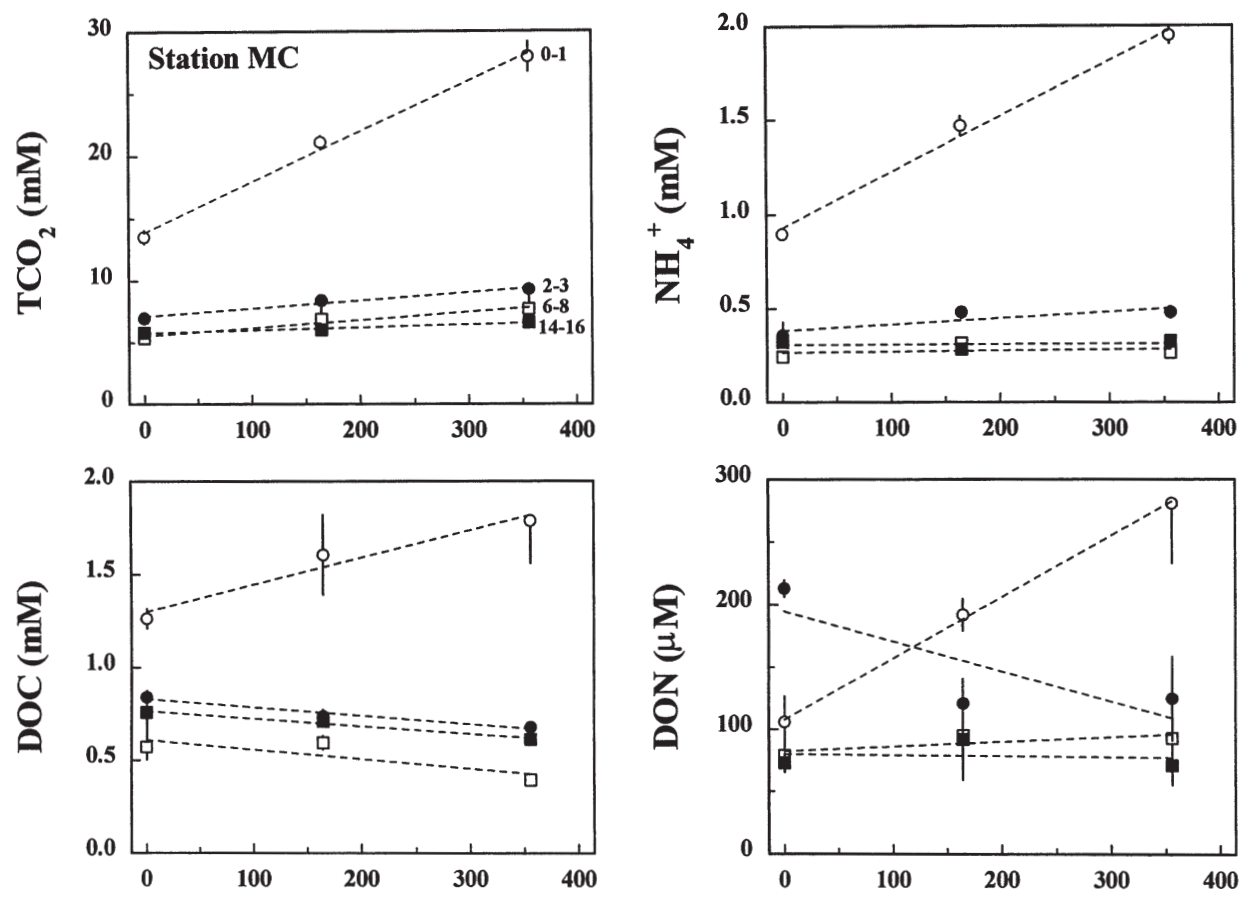

Fig. 2. Representative examples of changes in concentration of porewater $\mathrm{TCO}_{2}$, DOC, $\mathrm{NH}_{4}^{+}$and DON during jar incubations at Stn MC. Each data point represents the mean \pm range of duplicate jars. Numbers in the upper left panel indicate sediment depth intervals in $\mathrm{cm}$. Lines are drawn according to Time (h) least squares linear regression

\section{$\mathrm{CO}_{2}$ production $\left(\mu \mathrm{mol} \mathrm{cm}{ }^{-3} \mathrm{~d}^{-1}\right)$}
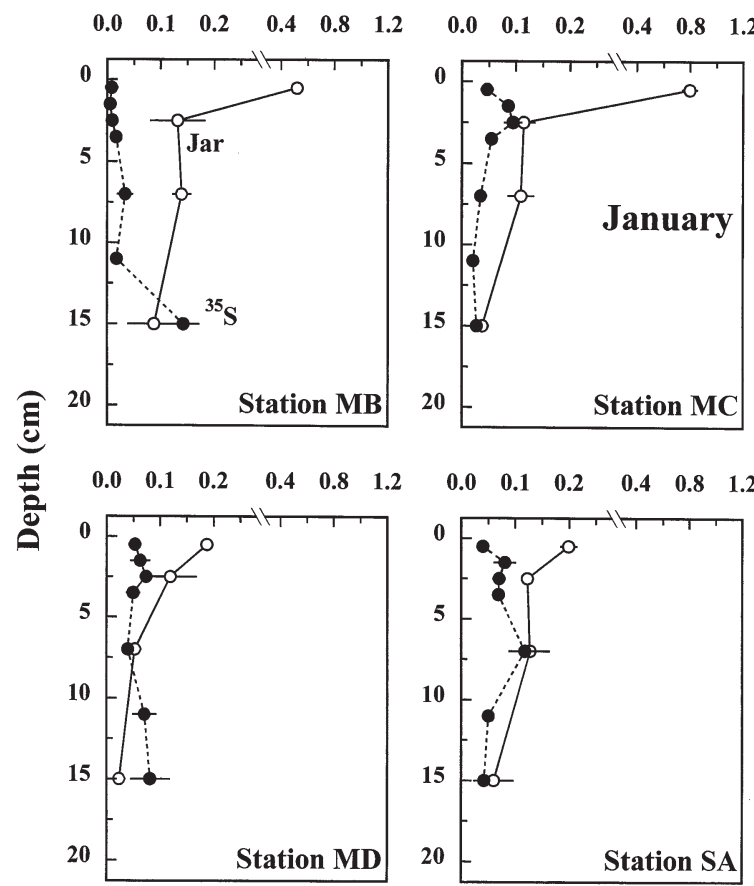

Fig. 3. $\mathrm{CO}_{2}$ production with depth in the sediment at Stns $\mathrm{MB}$, $\mathrm{MC}, \mathrm{MD}$ and SA during January (dry season). Rates obtained from jar incubations (o) and rates converted from ${ }^{35} \mathrm{~S}$ incubations by a C:S ratio of 2:1 (•) are shown. Data are given as mean values. Error bars represent $\pm \mathrm{SE}$ from regression analysis $(n=3)(j a r s)$ or of 3 replicates $\left({ }^{35} \mathrm{~S}\right)$

\section{$\mathrm{CO}_{2}$ production $\left(\mu \mathrm{mol} \mathrm{cm} \mathrm{c}^{-3} \mathrm{~d}^{-1}\right)$}

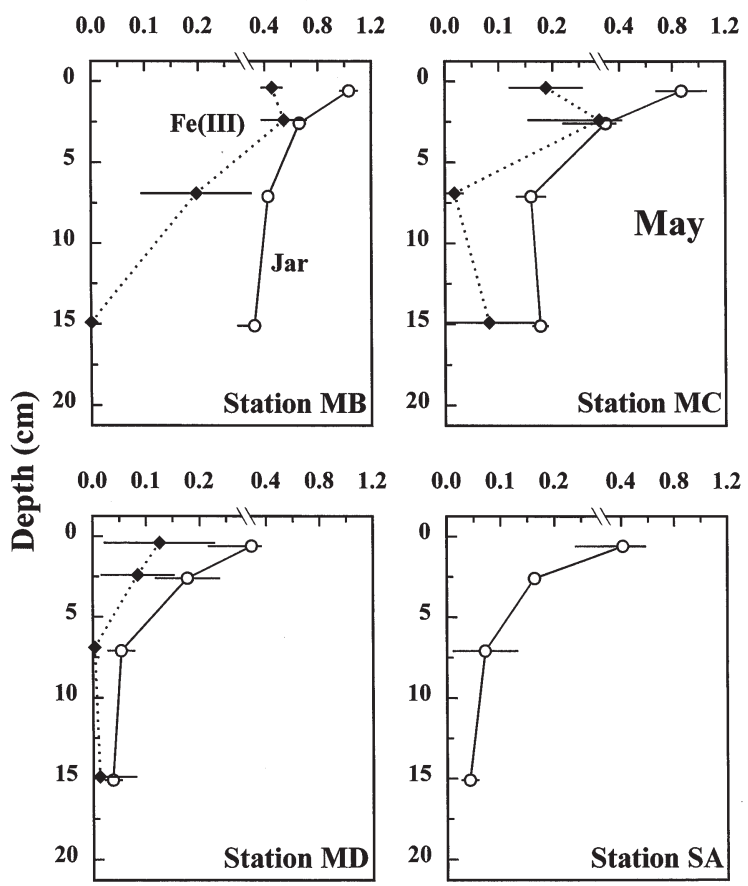

Fig. 4. $\mathrm{CO}_{2}$ production with depth in the sediment at Stns $\mathrm{MB}$, $\mathrm{MC}, \mathrm{MD}$ and SA during May (transition between dry and wet seasons). Jar incubation rates obtained directly from $\mathrm{CO}_{2}$ changes (O) and rates obtained from $\mathrm{Fe}(\mathrm{III})$ changes (converted to $\mathrm{C}$ units by a Fe:C ratio of $4: 1$ ) ( $\bullet$ ) are shown. Data are given as mean values. Error bars represent \pm SE from regression analysis $(\mathrm{n}=4)$ 
ration was generally responsible for 20 to $50 \%$ of total carbon oxidation in the upper $3 \mathrm{~cm}$ of the sediment at Stns $\mathrm{MB}, \mathrm{MC}$ and MD, except for the 2 to $3 \mathrm{~cm}$ interval in the rooted and bioturbated Stns $\mathrm{MB}$ and $\mathrm{MC}$, where the contribution was 80 to $95 \%$ (Fig. 4). The role of Fe(III) gradually diminished deeper in the sediment. The 0 to $16 \mathrm{~cm}$ depth-integrated Fe(III) respiration accounted for 35 to $45 \%$ of the total carbon oxidation in jars; this was highest at Stn MB and lowest at Stn MD (Table 3).

Net rates of DOC production were about 1 order of magnitude lower than those of $\mathrm{CO}_{2}$ production (-20 to $80 \mathrm{nmol} \mathrm{cm}^{-3} \mathrm{~d}^{-1}$ ). In fact, net consumption of DOC was evident in many cases (Fig. 6). Significant production of DOC was only observed at Stn MB, with depth-integrated rates ranging from 15 to $30 \%$ of $\mathrm{CO}_{2}$ production (Table 3). The shape of the DOC production profiles at this station was different in January and August, but remained within the same magnitude (Fig. 6). DOC rates at the other stations were low and varied between production and consumption with depth and season. There was no seasonal difference in depthintegrated rates at Stn $\mathrm{MC}\left(-20\right.$ to $30 \mathrm{nmol} \mathrm{cm} \mathrm{cm}^{-3} \mathrm{~d}^{-1}$, but Stns MD and SA showed low production in January (10 to $20 \mathrm{nmol} \mathrm{cm}^{-3} \mathrm{~d}^{-1}$ ) and similar consumption in August (Table 3).

Sediment nitrogen mineralization $\left(\mathrm{NH}_{4}{ }^{+}\right.$production) showed largely the same decreasing depth pattern as carbon mineralization (Fig. 7). Surface rates at Stn MC in January (60 $\mathrm{nmol} \mathrm{cm} \mathrm{cm}^{-3} \mathrm{~d}^{-1}$ ) were 2 to 3 times higher

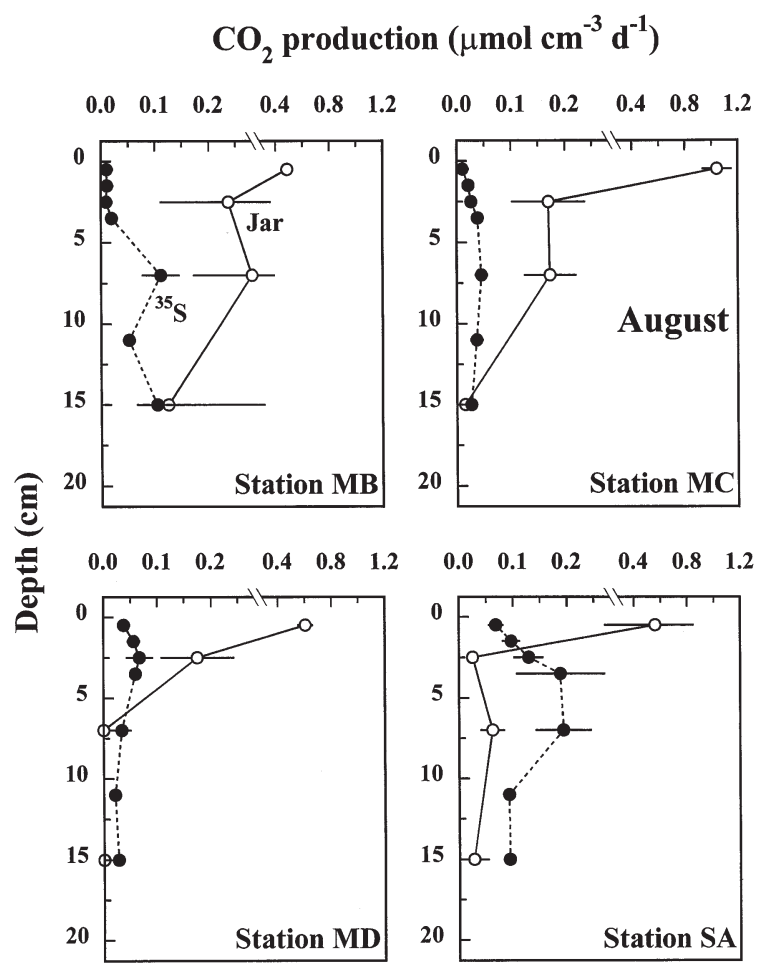

Fig. 5. $\mathrm{CO}_{2}$ production with depth in the sediment at Stns $\mathrm{MB}$, $\mathrm{MC}, \mathrm{MD}$ and SA during August (wet season). Rates obtained from jar incubations (o) and rates converted from ${ }^{35} \mathrm{~S}$ incubations by a C:S ratio of 2:1 $(\bullet)$ are shown. Data are given as mean values. Error bars represent $\pm \mathrm{SE}$ from regression analysis $(n=3)$ (jars) or of 3 replicates $\left({ }^{35} \mathrm{~S}\right)$

Table 3. Depth-integrated $(0-16 \mathrm{~cm})$ jar $\mathrm{CO}_{2}$ and DOC production rates ( 2 jar), depth-integrated $(0-16 \mathrm{~cm}) \mathrm{Fe}(\mathrm{III})$ reduction rates ( $\sum \mathrm{Fe}(\mathrm{III})$ red, given in $\mathrm{C}$ units based on a $\mathrm{C}: \mathrm{Fe}$ mineralization ratio of $\left.1: 4\right)$, depth-integrated $(0-16 \mathrm{~cm})$ sulfate reduction rates ( $\sum$ SRR, given in $\mathrm{C}$ units based on a $\mathrm{C}: \mathrm{S}$ mineralization ratio of 2:1) and dark flux of $\mathrm{O}_{2}, \mathrm{CO}_{2}$ and DOC (Flux, presented as mean \pm $\mathrm{SD}$ of 3 replicates), at the 4 Bangrong mangrove forest stations. $\sum \mathrm{Fe}$ (III) red at Stn SA is assumed to be O due to lack of any significant temporal pattern in jars (see text). Results are given for January, May and August. Negative values indicate uptake. Units are $\mathrm{mmol} \mathrm{m}^{-2} \mathrm{~d}^{-1}$

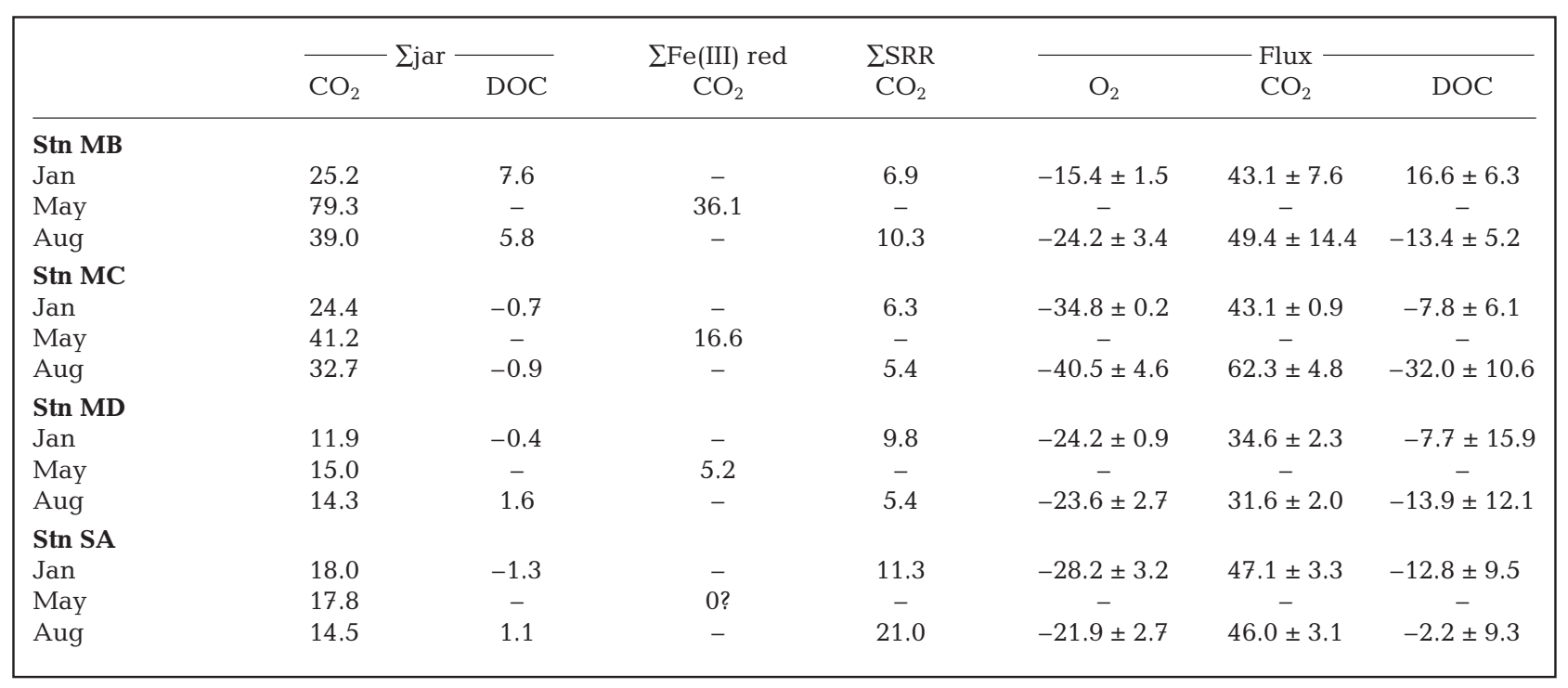




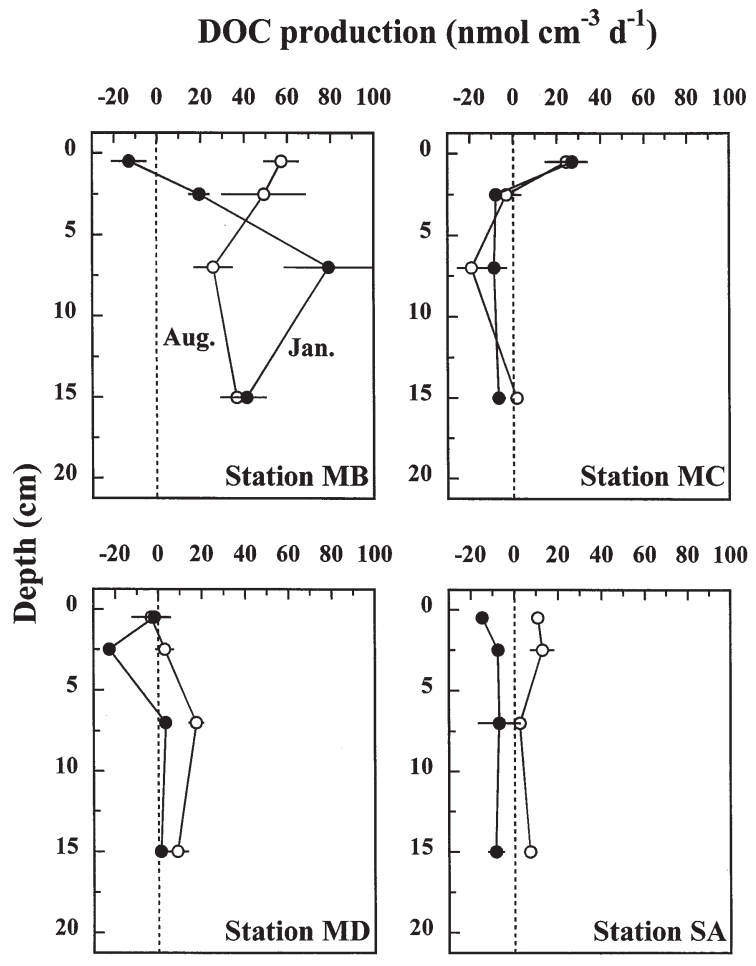

Fig. 6. DOC production with depth in the sediment at Stns MB, MC, MD and SA during January (•) and August (०). Rates are from jar incubations and given as mean values \pm SE from regression analysis $(n=3)$. Negative rates indicate consumption of DOC

than at Stns MB $\left(20 \mathrm{nmol} \mathrm{cm}{ }^{-3} \mathrm{~d}^{-1}\right)$ and MD (26 nmol $\left.\mathrm{cm}^{-3} \mathrm{~d}^{-1}\right)$, and almost 10 times higher than at Stn SA $\left(7 \mathrm{nmol} \mathrm{cm} \mathrm{cm}^{-3} \mathrm{~d}^{-1}\right.$ ), whereas Stns MB and MC had almost similar surface rates in August (18 and $24 \mathrm{nmol}$ $\left.\mathrm{cm}^{-3} \mathrm{~d}^{-1}\right)$, about 2 to 3 times higher than at Stns MD $\left(8 \mathrm{nmol} \mathrm{cm}{ }^{-3} \mathrm{~d}^{-1}\right)$ and SA $\left(9 \mathrm{nmol} \mathrm{cm}{ }^{-3} \mathrm{~d}^{-1}\right)$. Subsurface rates were 30 to $50 \%$ of the surface rates at Stns MB and MD, but only around $10 \%$ at Stns MC and SA in August. Net nitrogen mineralization did not decrease with depth at Stn SA in January. Depth-integrated rates were of the same magnitude at all stations in January, but decreased along the transect in August from a value slightly less than that found in January at Stn MB to only $20 \%$ of that at Stn SA (Table 4 ). The depthintegrated $\mathrm{C}: \mathrm{N}$ mineralization stoichiometry varied between 8 and 21 in January, with highest values at Stn MC and lowest at Stn MD. The C:N stoichiometries in August (29 to 66) were generally more than twice the January values (8 to 21 ).

DON showed a production/consumption pattern remarkably similar to that of DOC (Fig. 8), but with considerably lower rates (-8 to $10 \mathrm{nmol} \mathrm{cm}^{-3} \mathrm{~d}^{-1}$ ). Unfortunately, the results from August are missing due to analytical problems. Depth-integrated DON produc-

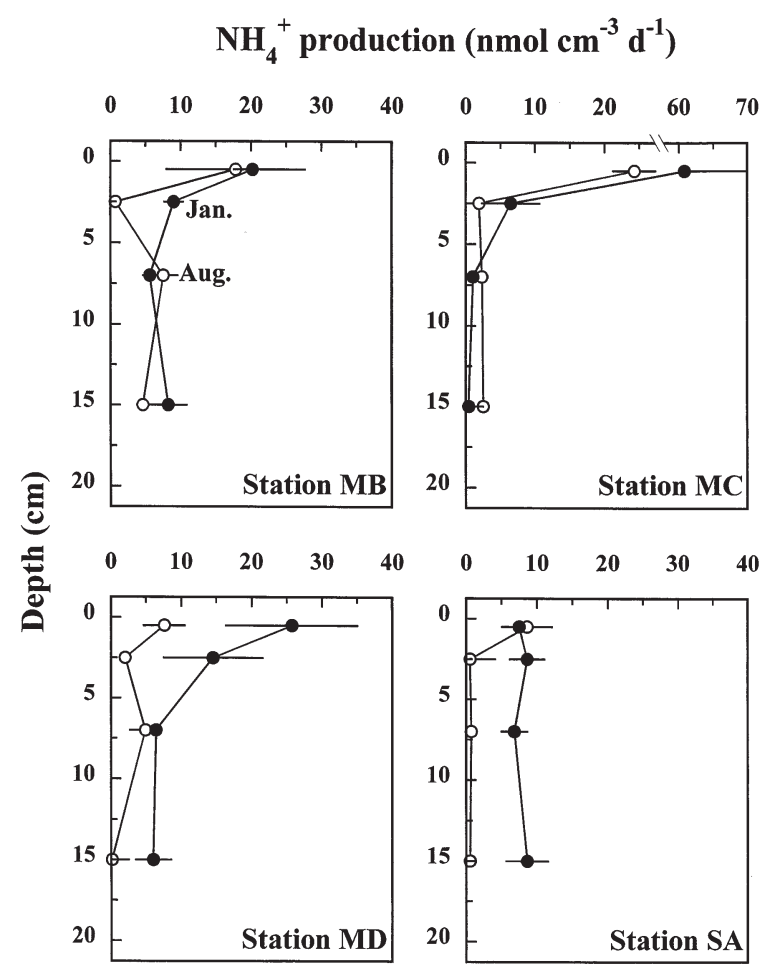

Fig. 7. $\mathrm{NH}_{4}{ }^{+}$production with depth in the sediment at Stns MB, MC, MD and SA during January (•) and August (०). Rates are from jar incubations and given as mean values $\pm \mathrm{SE}$ from regression analysis $(n=3)$

tion at Stn MB was about $10 \%$ of DOC production. No depth-integrated net production/consumption of DON was evident at Stn MC, whereas consumption rates at Stns MD and SA accounted for 55 and $8 \%$ of the DOC consumption.

\section{Sulfate reduction}

The depth pattern of sulfate reduction rates varied considerably among stations, but showed the same trend in both January and August (Figs. 3 \& 5). Stn MB had very low SRR (converted to carbon units by applying a C:S stoichiometry of 2:1; Froelich et al. 1979) of 5 to $10 \mathrm{nmol} \mathrm{cm}^{-3} \mathrm{~d}^{-1}$ in the upper $5 \mathrm{~cm}$ followed by gradually increasing rates with depth $\left(100\right.$ to $140 \mathrm{nmol} \mathrm{cm}^{-3}$ $\mathrm{d}^{-1}$ at 14 to $16 \mathrm{~cm}$ depth). Except for a small subsurface maximum at 2 to $3 \mathrm{~cm}$ depth in January (about

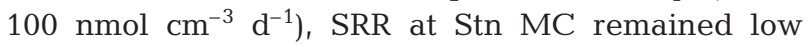
throughout the examined depth interval (20 to $50 \mathrm{nmol}$ $\mathrm{cm}^{-3} \mathrm{~d}^{-1}$ ). Stn MD showed a subsurface SRR maximum of about $70 \mathrm{nmol} \mathrm{cm}^{-3} \mathrm{~d}^{-1}$ at 2 to $3 \mathrm{~cm}$ depth followed by a slight decrease in August (reaching 20 to $40 \mathrm{nmol}$ $\mathrm{cm}^{-3} \mathrm{~d}^{-1}$ ) and a gradual increase in January (reaching 
Table 4. Depth-integrated $(0-16 \mathrm{~cm})$ jar $\mathrm{NH}_{4}{ }^{+}$production rates $\left(\sum \mathrm{jar}\right)$ and dark flux (Flux) of $\mathrm{NH}_{4}{ }^{+}$and $\mathrm{NO}_{3}{ }^{-}\left(=\sum \mathrm{DIN}\right)$ at the 4 Bangrong mangrove forest stations. The molar C:N stoichiometry $\left(\mathrm{CO}_{2}\right.$ rates/ $\mathrm{NH}_{4}{ }^{+}$rates $)$are shown for depth-integrated jar mineralization (see Table 2 for $\mathrm{CO}_{2}$ data). Results are given for January and August. Fluxes are presented as mean \pm SD of 3 replicates. Negative values indicate uptake. Units are $\mathrm{mmol} \mathrm{m}^{-2} \mathrm{~d}^{-1}$

\begin{tabular}{|c|c|c|c|c|c|}
\hline & \multicolumn{2}{|c|}{- Ljar } & \multicolumn{3}{|c|}{ Flux } \\
\hline & $\mathrm{NH}_{4}^{+}$ & $\mathrm{C}: \mathrm{N}$ & $\mathrm{NH}_{4}^{+}$ & $\mathrm{NO}_{3}^{-}$ & $\sum \mathrm{DIN}$ \\
\hline \multicolumn{6}{|c|}{ Stn MB } \\
\hline Jan & 1.35 & 18.7 & $-0.08 \pm 0.02$ & $-0.03 \pm 0.01$ & -0.11 \\
\hline Aug & 1.01 & 38.6 & $-2.20 \pm 0.03$ & $-0.34 \pm 0.59$ & -2.54 \\
\hline \multicolumn{6}{|c|}{ Stn MC } \\
\hline Jan & 1.19 & 20.5 & $-0.36 \pm 0.19$ & $-0.04 \pm 0.01$ & -0.40 \\
\hline Aug & 0.70 & 46.7 & $0.77 \pm 0.32$ & $-0.80 \pm 0.02$ & -0.10 \\
\hline \multicolumn{6}{|c|}{ Stn MD } \\
\hline Jan & 1.54 & 7.7 & $-0.22 \pm 0.15$ & $0.06 \pm 0.02$ & -0.16 \\
\hline Aug & 0.50 & 28.6 & $-0.47 \pm 0.36$ & $0.09 \pm 0.16$ & -0.38 \\
\hline \multicolumn{6}{|c|}{ Stn SA } \\
\hline Jan & 1.24 & 14.5 & $1.74 \pm 0.48$ & $0.48 \pm 0.04$ & 2.22 \\
\hline Aug & 0.22 & 65.9 & $0.00 \pm 0.00$ & $-0.02 \pm 0.01$ & -0.02 \\
\hline
\end{tabular}

$80 \mathrm{nmol} \mathrm{cm}^{-3} \mathrm{~d}^{-1}$ ) further down in the sediment. At Stn SA the subsurface maximum was much broader (from 2 to $8 \mathrm{~cm}$ depth) than at the other stations. SRR was almost 2 times higher in August (70 to $190 \mathrm{nmol} \mathrm{cm} \mathrm{cm}^{-3}$

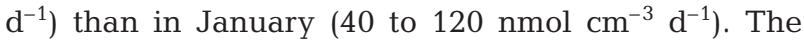
depth-integrated SRR was about a factor of 2 higher at Stn SA than at the other stations with no general seasonal pattern (Table 3).

\section{Fluxes}

The release of $\mathrm{CO}_{2}$ from darkened and inundated sediment ranged between 32 and $62 \mathrm{mmol} \mathrm{m}^{-2} \mathrm{~d}^{-1}$ (Table 3). $\mathrm{CO}_{2}$ release appeared to be 20 to $50 \%$ lower at Stn MD than at the other stations. Only Stn MC showed a significant seasonal difference, with about $50 \%$ higher rates in August than in January. Oxygen uptake was always lower than $\mathrm{CO}_{2}$ release, with highest rates at Stn MC (Table 3$)$. The respiratory quotient $\left(=\mathrm{CO}_{2}\right.$ flux $/ \mathrm{O}_{2}$ flux $)$ was highest at Stn MB (2.0 to 2.8), intermediate at Stn SA (1.7 to 2.1) and lowest at Stns $\mathrm{MC}$ and MD (1.2 to 1.5).

The DOC fluxes varied among stations and between seasons, with much larger coefficients of variation than for the $\mathrm{O}_{2}$ and $\mathrm{CO}_{2}$ flux (Table 3). The 3 mangrove stations (Stns MB, MC and MD) all showed higher sediment uptake of DOC from the overlying water in August than in January. A surprising, but significant, DOC efflux equivalent to $40 \%$ of the $\mathrm{CO}_{2}$ release was observed at Stn MB in January. Otherwise, the sediment at the 3 mangrove stations consumed DOC at rates equivalent to $20-50 \%$ of the $\mathrm{CO}_{2}$ release, whereas DOC only accounted for $5-30 \%$ of the $\mathrm{CO}_{2}$ release at the seagrass station (Stn $\mathrm{SA})$.

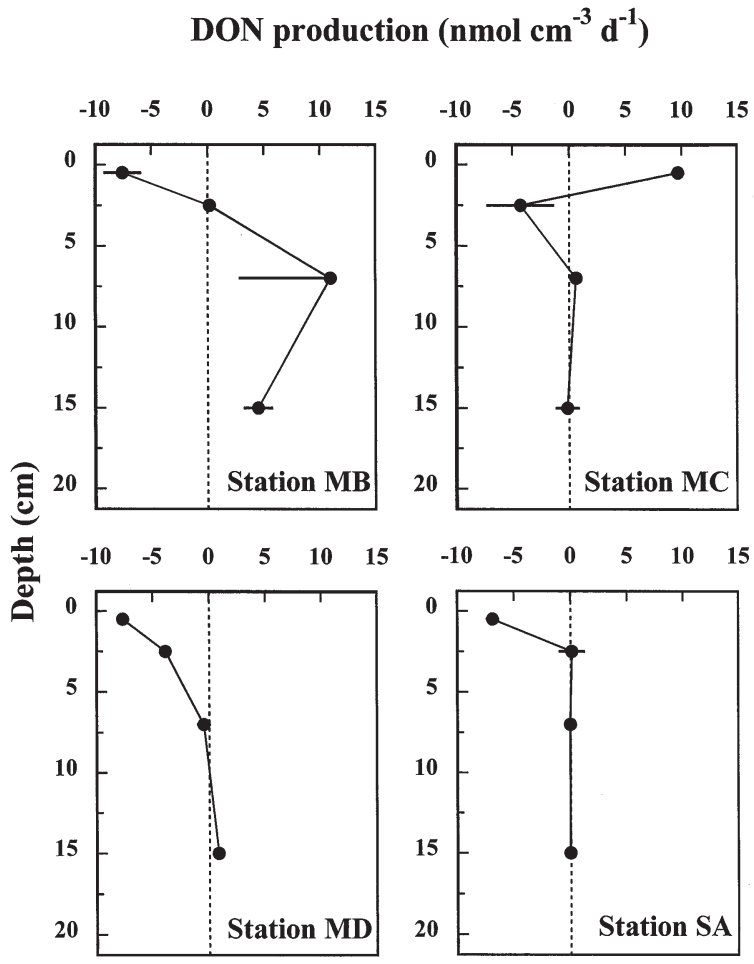

Fig. 8. DON production with depth in the sediment at Stns $\mathrm{MB}, \mathrm{MC}, \mathrm{MD}$ and SA during January. Rates are from jar incubations and given as mean values $\pm \mathrm{SE}$ from regression analysis $(n=3)$. Negative rates indicate consumption of DON

The fluxes of $\mathrm{NH}_{4}{ }^{+}$and $\mathrm{NO}_{3}^{-}$across the sedimentwater interface were low and in many cases directed into the sediment (Table 4). There was no significant pattern among stations and between seasons and the coefficients of variation were often so high that the fluxes were not significantly different from zero. How- 
ever, the total flux of dissolved inorganic nitrogen ( DIN) was generally directed into the sediment, with the exception of Stn SA in January.

\section{Methodological considerations}

The 3 techniques (sediment-water flux, jar incubation, and ${ }^{35} \mathrm{~S}_{-} \mathrm{SO}_{4}{ }^{2-}$ injection) used here for quantification of mineralization rates are frequently used approaches in marine sediments (e.g. Fossing \& Jørgensen 1989, Kristensen \& Hansen 1995), but they have been used simultaneously in only few studies (e.g. Canfield et al. 1993). They all have advantages and disadvantages, but their simultaneous use provides a more differentiated assessment of total mineralization rates and down core pattern of reaction rates.

Sediment-water fluxes of $\mathrm{O}_{2}, \mathrm{CO}_{2}$ and DIN are usually considered representative and reliable measures of total benthic metabolism in submerged sediments (Andersen \& Helder 1987, Archer \& Devol 1992). However, the use of cylindrical core tubes with circular water flow during sediment incubations may, particularly in sandy sediments, overestimate solute fluxes under natural conditions with laminar flow (Huettel \& Gust 1992).

The jar technique determines anaerobic mineralization directly as net accumulation of metabolic end products (e.g. $\mathrm{TCO}_{2}$ and $\mathrm{NH}_{4}{ }^{+}$) or consumption of electron acceptors (e.g. $\mathrm{Fe}(\mathrm{III})$ and $\mathrm{SO}_{4}{ }^{2-}$ ) in homogenized sediment using a long-term incubation period. Mixing and homogenization may temporarily destroy the natural chemical, physical and biological structure of the sediment, but it has been shown (Sun et al. 1991) that effects of such manipulations are relatively short-term relative to an incubation time of weeks. On the other hand, the supply of oxidation equivalents is blocked due to the closed nature of jars and sulfate reduction will eventually replace all respiration processes using electron acceptors more potent than sulfate (e.g. $\mathrm{O}_{2}$, $\mathrm{NO}_{3}{ }^{-}, \mathrm{Mn}^{4+}, \mathrm{Fe}^{3+}$ ) (Kristensen \& Hansen 1995). It appeared, however, that in the present experiment the initial $\mathrm{Fe}(\mathrm{III})$ content was sufficient to maintain active $\mathrm{Fe}(\mathrm{III})$ reduction throughout the incubation period.

When sulfate reduction is measured by the nondestructive ${ }^{35}$ S-injection technique, the obtained down core profiles can be considered in situ rates when reoxidation of $\mathrm{H}_{2}{ }^{35} \mathrm{~S}$ during incubations is assumed insignificant (Fossing 1995). The ${ }^{35} \mathrm{~S}$-sulfate reduction approach provides a measure of carbon mineralized only in the reduced sediment (Fossing \& Jørgensen 1989), whereas the jar approach basically represents a measure of total carbon mineralization within the entire sediment column, including oxic and suboxic layers (Kristensen \& Hansen 1995).

\section{DISCUSSION}

The Bangrong mangrove area is, as most mangrove environments, characterized by changing physical conditions caused by tidal currents, wave action and light-dark cycles as well as by spatial heterogeneity of the sediment due to plant roots and infaunal bioturbation (Alongi et al. 1998, Holmer et al. 1999). These more or less predictable conditions restrict a precise quantitative evaluation of sediment biogeochemistry as indicated here by considerable spatial and temporal fluctuations in carbon and nitrogen transformations.

The lack of any significant seasonal difference of fluxes and mineralization in the Bangrong area is in accordance with the limited seasonal change in key parameters like temperature and litter fall (Chansang \& Poovachiranon 1990, Holmer et al. 1999). Only salinity and thus sulfate concentration in surface sediments may vary, with lower concentrations after heavy rain periods in the wet season than during sunny periods with strong evaporation in the dry season (Holmer et al. 1999).

\section{Carbon oxidation and partitioning of electron acceptors}

Carbon oxidation in marine sediments is controlled by the availability of labile organic carbon and electron acceptors. The efflux of $\mathrm{CO}_{2}$ in the Bangrong area is comparable to rates of benthic metabolism found for other mangrove sediments (Table 3; Alongi 1994, Kristensen et al. 1994, Nedwell et al. 1994), but the generally poor detritus quality may explain the relatively low fluxes compared with intertidal coastal environments in colder temperate climates (Mackin \& Swider 1989, Magenheimer et al. 1996, Alongi 1997). The relatively high rates of $\mathrm{CO}_{2}$ production measured by jar incubations in the uppermost $\mathrm{cm}$ of the sediment at all locations (Figs. 3 to 5) are typical for sediments with a continuous input of organic matter to the surface (Burdige 1991, Canuel \& Martens 1996). In the present case, the organic input is mostly in the form of mangrove and seagrass litter and microphytobenthic production (Chansang \& Poovachiranon 1990, Alongi 1997, Wafar et al. 1997). The decreasing rates observed with depth must be caused by exhaustion of the labile organic pools, since porewater sulfate concentrations down to at least $15 \mathrm{~cm}$ depth remained within a range of 20 to $30 \mathrm{mM}$ (data not shown) and were thus not limiting for sulfate reduction.

The total pool of organic matter in sediments can be described as a reactive continuum, where the largest part of the total pool is refractory and only a small part is degradable within the time scale examined here 
(Henrichs \& Reeburgh 1987). In most sediments the small reactive pool decreases with depth in a pattern similar to the vertical profiles of $\mathrm{CO}_{2}$ production found here, while the refractory pool is large and remains almost constant with depth. The refractory pool appears to be proportionally largest at the mangrove stations as indicated by a 7 times higher sediment POC content (Table 1), but with no corresponding trend in benthic metabolism (measured as $\mathrm{CO}_{2}$ flux and $\mathrm{CO}_{2}$ production in jars) when moving from Stn $\mathrm{MB}$ to $\mathrm{Stn}$ SA (Table 3). Living mangrove leaves contain about $50 \%$ lignocellulose, a highly refractory structural complex consisting of the aromatic heteropolymer lignin, in close physical and covalent association with the polysaccharides, cellulose and hemicellulose (Benner \& Hodson 1985). The non-lignocellulose components of the leaves are mostly soluble carbohydrates that rapidly leach from the leaves after submersion in water (Neilson \& Richards 1989). Although, tannins and other phenolic compounds with microbial inhibitory potential may account for a significant fraction (18\%) of the DOM in mangrove leachate (Benner et al. 1986), the released DOC fraction is degraded rapidly in the mangrove environment (Benner et al. 1986, Kristensen \& Pilgaard 2000), leaving the recalcitrant lignocellulosic detritus to be deposited and buried in the sediment.

The different down core patterns of $\mathrm{CO}_{2}$ production estimated from sulfate reduction $\left({ }^{35} \mathrm{~S}\right)$ and jar incubation reflect the redox conditions and availability of electron acceptors within the sediment. Sulfate reduction is usually hampered in the uppermost oxidized surface layer, where more potent electron acceptors are available from above (Canfield et al. 1993). In the vegetated Stn $\mathrm{MB}$ and bioturbated Stn MC, where root excretion of oxygen (Andersen \& Kristensen 1988) and downward transport of oxygen via burrows (Aller 1990, Ridd 1996) increase the redox and thus the Fe(III) content (Table 2) in deeper layers, sulfate reduction remains considerably lower than jar rates down to about $15 \mathrm{~cm}$ depth (Figs. 3 \& 5). The good correspondence between the estimated suboxic $\mathrm{CO}_{2}$ production (difference between $\mathrm{CO}_{2}$ production in jars minus the contribution from sulfate reduction) and the estimated $\mathrm{CO}_{2}$ production from $\mathrm{Fe}$ (III) reduction (based on a Fe:C ratio of 4:1) indicate that the latter process is responsible for most, if not all, suboxic respiration (Fig. 9). In these calculations we assume that all Fe(III) reduction is used for carbon oxidation by microbial respiration (see below). In freshwater wetland sediments with amorphous Fe(III) oxide concentrations similar to those found in the present mangrove sediment, Roden \& Wetzel (1996) demonstrated that microbial Fe(III) reduction suppressed sulfate reduction and methanogenesis in surface sediments. Also in accordance with Roden \& Wetzel (1996), no suboxic $\mathrm{CO}_{2}$ production is

\section{Suboxic $\mathrm{CO}_{2}$ production $\left(\mu \mathrm{mol} \mathrm{cm} \mathrm{cm}^{-3} \mathrm{~d}^{-1}\right)$}

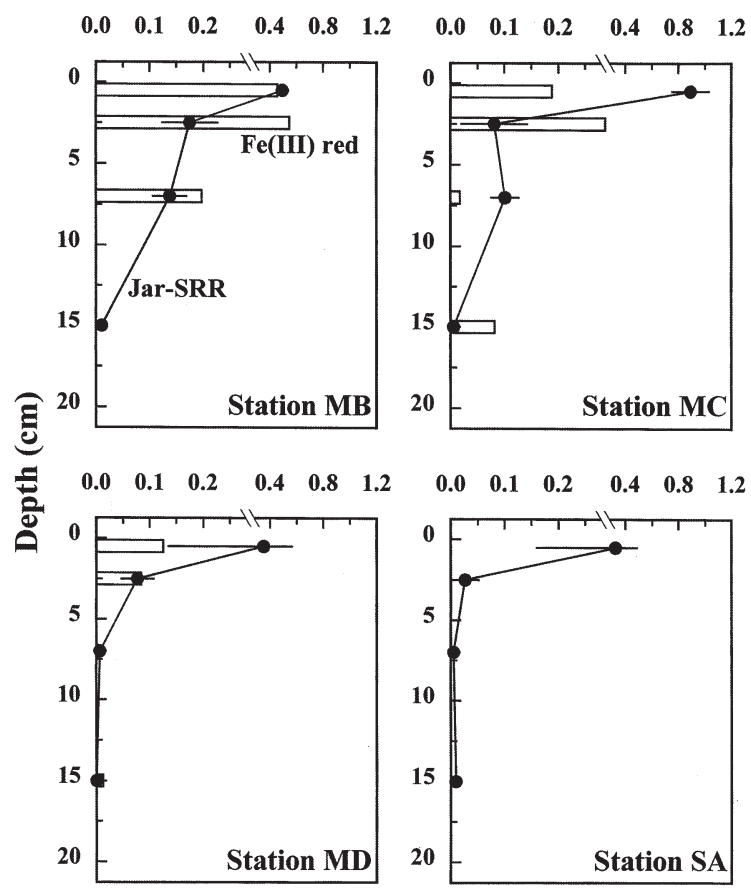

Fig. 9. Suboxic $\mathrm{CO}_{2}$ production in the sediment at Stns $\mathrm{MB}$, $\mathrm{MC}, \mathrm{MD}$ and SA. Connected solid symbols represent the excess $\mathrm{CO}_{2}$ evolution in jars with depth in the sediment after subtraction of the estimated contribution from sulfate reduction (Jar-SRR; mean \pm range of results from January and August). Negative values have been plotted as zero. Open bars represent the $\mathrm{CO}_{2}$ evolution estimated from $\mathrm{Fe}(\mathrm{III})$ reduction in jars (results from May, see Fig. 4)

evident below 3 to $5 \mathrm{~cm}$ depth in the 2 less bioturbated and vegetated Stns $\mathrm{MC}$ and SA sediments from the Bangrong area. Here anaerobic carbon mineralization below $5 \mathrm{~cm}$ depth apparently is due entirely to sulfate reduction. Significant Fe(III) reduction was only evident in the upper few $\mathrm{cm}$ at Stn MD. A similar depth pattern has been observed previously in non-vegetated marine sediments, with higher jar rates in the upper oxic/suboxic surface zone mainly supplied by metal respiration and comparable jar and ${ }^{35} \mathrm{~S}$-sulfate reduction rates in deeper layers (Canfield et al. 1993, Kristensen et al. 1999).

The partitioning of total carbon oxidation in Bangrong sediments can be deciphered from 0 to $16 \mathrm{~cm}$ depth-integrated rates and measured fluxes (Table 3). The dominating microbial processes in the sediments are assumed to be aerobic respiration (OxR), Fe(III) reduction (FeR) and sulfate reduction (SRR), while $\mathrm{CO}_{2}$ efflux from the sediments is considered a measure of total carbon oxidation (TR). Accordingly, carbon oxidation by aerobic respiration is: $\mathrm{OxR}=\mathrm{TR}-\mathrm{FeR} / 4-$ 2SRR, where the contribution of Fe(III) reduction and 
sulfate reduction is converted to carbon units using standard stoichiometries (Froelich et al. 1979).

However, 4 major concerns should be considered in the partitioning calculations: (1) Since we only measured $\mathrm{CO}_{2}$ fluxes under submerged conditions, the total carbon oxidation used in our calculations may be underestimated. Drainage of water from sediment interstices (burrows and cracks) during low tide, particularly in the vegetated site (Stn MB) may increase the area of air-sediment interfaces and thus significantly enhance the flux of gases (Kristensen et al. 1992, Holmer et al. 1999). (2) Although chemical or microbial oxidation of sulfides can occur with Fe(III) as oxidant (Kostka \& Luther 1995, Luther et al. 1996), we assume that most Fe(III) reduction in our jar is used for carbon oxidation by microbial respiration. Thus, a test confirmed that newly produced sulfides were not oxidized by Fe(III) because a jars series with molybdate addition to inhibit sulfate reduction provided the same Fe(III) reduction as a parallel unamended series (data not shown). All sulfides are instead readily scavenged and precipitated by the high concentrations (up to $2 \mathrm{mM}$ ) of dissolved porewater $\mathrm{Fe}^{2+}$ (Kostka \& Luther 1995). (3) The standard stoichiometries used in the conversion of $\mathrm{Fe}(\mathrm{III})$ reduction (Fe:C $=4: 1$ ) and sulfate reduction ( $\mathrm{C}: \mathrm{S}=2: 1)$ to carbon oxidation units depend on the oxidation state of organic carbon and may vary depending on the origin and age of the sediment detritus (Hammond et al. 1996). The role of sulfate reduction obtained here may, however, be underestimated and that of oxic respiration overestimated because Holmboe et al. (unpubl.) have observed that the C:S ratio of carbon mineralization by sulfate reduction may be up to twice as high in mangrove sediments as the standard ratio of 2:1 used to convert sulfate reduction to carbon units. (4) Only Fe(III) oxide respiration is included in our calculations, whereas other suboxic processes (denitrification and Mn(IV) oxide reduction) are ignored. However, since nitrate levels and denitrification rates are usually very low in mangrove sediments (Rivera-Monroy \& Twilley 1996, Kristensen et al. 1998), and manganese is almost absent in the Bangrong mangrove area (0 to $4 \mu \mathrm{mol} \mathrm{Mn} \mathrm{g}{ }^{-1} \mathrm{dw}$, Holmboe et al. unpubl.) as well as other mangrove forests (Alongi 1997), these 2 potential electron acceptors must be considered to be of limited importance for benthic respiration. Their (minor) contribution is therefore included in our estimate of aerobic respiration.

Based on the considerations above, partitioning calculations suggest that oxic respiration is responsible for at least 0 to $6 \%$ of the total carbon mineralization in vegetated mangrove sediment (Stn MB) and 47 to $65 \%$ in biotur- bated mangrove sediment (Stn MC) (Table 5). In the less disturbed, but more sandy sediments (Stns MD and SA) aerobic processes are responsible for 55 to $75 \%$ of the total. An average of 92 and $20 \%$ of the measured oxygen uptake at Stns MB and MC must be devoted to reoxidation of reduced metabolites, while only an average of 15 and $0 \%$ of the oxygen demand is channeled in this direction at Stns MD and SA. Since no free sulfide was detected in any of the sediments, $\mathrm{Fe}^{2+}$ oxidation is probably most important. Accordingly, porewater from $\mathrm{Stn} \mathrm{MB}$ was rich in $\mathrm{Fe}^{2+}$ (2 to $3 \mathrm{mM}$ at $10 \mathrm{~cm}$ depth); Stn MC was intermediate with respect to dissolved $\mathrm{Fe}^{2+}$ (0.5 to $1.0 \mathrm{mM}$ ), whereas Stns MD and SA only contained traces of dissolved $\mathrm{Fe}^{2+}$ (less than $100 \mu \mathrm{M})$. In comparison, Luther et al. (1996) found that $67 \%$ of the oxygen uptake in a salt marsh sediment was used for $\mathrm{Fe}^{2+}$ oxidation. The role of sulfate reduction increased from $9-21 \%$ in the disturbed mangrove sediments to $27-46 \%$ at the less disturbed sites. The contribution of Fe(III) respiration, on the other hand, decreased rapidly along the transect from $73-84 \%$ within the mangrove forest to $27-39 \%$ in the bioturbated mudflat devoid of roots, followed by a more gradual decrease to $\sim 0$ in the seagrass bed. Despite the spatial variation, these proportions are comparable to data from other marine areas (Thamdrup 2000), and a number of studies have reported considerable variation within and between mangrove and salt marsh environments (Nedwell et al. 1994, Middelburg et al. 1996, Alongi 1997). King \& Garey (1999) demonstrated that aquatic macrophyte roots actually harbor active populations of Fe(III) reducers. Roots of mangrove trees may therefore substantially increase the volume of sediment in which Fe(III) reduction occurs, contributing to the very high Fe(III) respiration found within the mangrove forest. It is evident that sulfate reduction is not always the dominant diagenetic pathway in mangrove forests, and that oxic and suboxic processes may predominate, depending on factors such as sediment particle size, inundation frequency, forest type, organic content and bioturbation activity (Alongi 1997).

Table 5. Relative percentage contribution of oxic respiration $\left(\mathrm{O}_{2}\right.$ reduction; includes a minor contribution from $\mathrm{NO}_{3}{ }^{-}$and $\mathrm{Mn}(\mathrm{IV})$ reduction), iron respiration (Fe(III) reduction) and sulfate respiration (sulfate reduction) to the total carbon oxidation in the 3 mangrove forest sediments and 1 seagrass sediments at Bangrong. Iron respiration at Stn SA is assumed to be O due to lack of any significant temporal pattern in jars. Results are given as ranges of the January, May and August experiments. See text for details

\begin{tabular}{|lccc|}
\hline Stn & Oxic respiration & Iron respiration & Sulfate reduction \\
\hline MB & $0.2-6.0$ & $73.1-83.8$ & $16.0-20.9$ \\
MC & $46.9-64.7$ & $26.6-38.5$ & $8.7-14.6$ \\
MD & $56.6-66.5$ & $15.0-16.5$ & $17.1-28.3$ \\
SA & $54.3-76.0$ & $0 ?$ & $24.0-45.7$ \\
\hline
\end{tabular}


Although downward translocation of oxidation equivalents by plants and animals are important to maintain a high Fe(III) oxide reduction in sediments, the availability of iron also appears to be crucial (Canfield et al. 1993). Accordingly, the actively Fe(III) reducing Bangrong mangrove sediments (Stns MB and MC) are rich in iron (Table 2) and a large fraction (15 to $30 \%$ ) is found as reactive amorphous Fe(III) oxide with a high potential for microbial reduction. The diminishing role of $\mathrm{Fe}(\mathrm{III})$ reduction along the transect is therefore a reflection of both decreasing iron content and less disturbed subsurface conditions by oxidizing agents like tree roots and bioturbating crab fauna. Past studies conducted in iron-poor salt marshes have shown that microbial reduction of Fe(III) occur in vegetated sediments, but that the microbial process due to iron limitation accounts for a minor fraction of total carbon oxidation (Howarth 1993). In vegetated freshwater wetlands rich in iron, on the other hand, Fe(III) respiration may mediate more than half of the anoxic carbon oxidation (Roden \& Wetzel 1996).

The direct uptake of DOC from the water column in the Bangrong area, and possible subsequent oxidation in surface sediment, may contribute to the measured $\mathrm{CO}_{2}$ efflux at, particularly, the most flooded low-intertidal sites. This carbon source is unaccounted for in the jar assay, contributing to the apparent underestimate of depth-integrated jar rates. By subtracting the DOC contribution from $\mathrm{CO}_{2}$ fluxes, a good agreement between fluxes and depth-integrated jar rates can be obtained in many cases (Table 3). Several lines of evidence suggest that the microbial community of the oxic sediment surface in mangrove forests is an efficient scavenger of DOC from both the overlying water and underlying anoxic sediment (Alongi 1997). The efflux of DOC across the sediment-water interface is small and insignificant in Australian mangrove forests despite porewater concentrations as high as 1 to $4 \mathrm{mM}$ and a steep concentration gradient in the upper cm (Stanley et al. 1987, Boto et al. 1989). The porewater concentration of DOC in the Bangrong mangrove forest is 0.5 to $1.0 \mathrm{mM}$, and the gradient near the sedimentwater interface clearly indicates an efflux in contrast to the measured influx (Holmer et al. unpubl.). The seasonal difference in measured DOC influx, generally with highest rates in August, is probably controlled by the concentration in the overlying water, which varies from 200 to $500 \mu \mathrm{M}$ in August and 100 to $300 \mu \mathrm{M}$ in January (authors' pers. obs.).

\section{Nitrogen mineralization and C:N stoichiometry}

The significant production of $\mathrm{NH}_{4}{ }^{+}$found in jars was not balanced by dark fluxes of DIN across the sedi- ment-water interface (Table 4). On the contrary, DIN fluxes were directed into the sediment in most cases. The missing $\mathrm{NH}_{4}{ }^{+}$cannot be ascribed to uptake by rooted plants (trees and seagrasses) in the present study, because roots were either cut or removed from the sediment before incubations. The high $\mathrm{NH}_{4}{ }^{+}$ demand must instead be assigned to assimilation during microbial degradation of nutrient-poor tree and seagrass tissues in the sediment (Alongi 1996, RiveraMonroy \& Twilley 1996). Since heterotrophic bacteria generally need organic substrates with a $\mathrm{C}: \mathrm{N}$ ratio of 10 or less for maintenance and growth (Fenchel \& Blackburn 1979), mangrove and seagrass litter with C:N ratios of up to 100 (Kristensen 1990) are a highly insufficient substrate. This is supported by the high POC:PON ratio of detritus in Bangrong sediment (Table 1 ) and the considerably higher $\mathrm{C}: \mathrm{N}$ ratio of mineralization products (8 to 66; Table 4) compared with other coastal marine sediments (around 4; Kristensen \& Hansen 1995). The cycling of inorganic nitrogen must therefore be rapid and efficient, but hardly sufficient to support optimal bacterial growth.

Based on our depth profiles of net $\mathrm{NH}_{4}{ }^{+}$production and data from Holmer et al. (unpubl.) on porewater $\mathrm{NH}_{4}{ }^{+}$ concentrations (10 to $150 \mu \mathrm{M}$ ), the turnover time of dissolved $\mathrm{NH}_{4}{ }^{+}$can be estimated to range from around $1 \mathrm{~d}$ in the surface layer ( 0 to $1 \mathrm{~cm}$ ), where ammonification is rapid, to weeks or months in the less reactive subsurface layers. A rapid turnover of $<1 \mathrm{~d}$ in surface sediment has been reported from other tropical mangrove forests (Nedwell et al. 1994). It has been suggested that $\mathrm{NH}_{4}{ }^{+}$is trapped in the upper few $\mathrm{cm}$ of mangrove sediments due to a tight coupling between microbial mineralization and assimilation in this highly reactive zone (Alongi 1996, Kristensen et al. 1998). The rapid turnover of $\mathrm{NH}_{4}{ }^{+}$in mangrove sediments is substantiated by the fact that our net ammonification rates are comparable to those found in other mangrove sediments (Hines \& Lyons 1982, Iizumi 1986), but only 1 to $10 \%$ of the gross rates reported by Nedwell et al. (1994).

\section{CONCLUSIONS}

Rates of carbon oxidation in sediments of the Bangrong area are controlled by the availability of labile organic carbon and electron acceptors. Suboxic respiration with amorphous Fe(III) oxide as electron acceptor accounts for about $80 \%$ of the total carbon oxidation in the fine-grained and organic-rich vegetated sediment within the mangrove forest, whereas sulfate reduction is responsible for about $20 \%$ and aerobic respiration for about $<6 \%$. In the adjacent bioturbated mudflat, the role of sulfate reduction decreases to about $10 \%$ and aerobic respiration increases to about 50 to $60 \%$, while 
iron respiration decreases to about 30 to $40 \%$. The partitioning of sediment respiration changes significantly in the organic-poor sand flat and seagrass meadow outside the mangrove forest. Here iron respiration only accounts for 0 to $16 \%$, whereas sulfate reduction is responsible for 20 to $35 \%$ of the total carbon oxidation. However, the most important electron acceptor in this area is oxygen (55 to $75 \%$ ). The shift in dominance of electron acceptors along the transect is primarily related to the presence of roots and bioturbating infauna, but the decreasing availability of iron may cause the diminishing role of this electron acceptor. The net production of ammonium in the sediment is not balanced by fluxes of DIN across the sediment-water interface. The missing nitrogen is assigned to a rapid (turnover time of $1 \mathrm{~d}$ ) and efficient bacterial ammonium assimilation at the sediment surface.

Acknowledgements. We are grateful to the staff of Phuket Marine Biological Center for providing facilities and invaluable assistance during this study. We thank $\mathrm{H}$. Brandt for technical assistance. This work was supported by DANIDA (SCP-project) and SNF (grant no. 9601423)

\section{LITERATURE CITED}

Aller RC (1990) Bioturbation and manganese cycling in hemipelagic sediments. Phil Trans R Soc Lond A 331:51-68

Aller RC (1994) The sedimentary Mn cycle in Long Island Sound: its role as intermediate oxidant and the influence of bioturbation, $\mathrm{O}_{2}$ and $\mathrm{C}_{\text {org }}$ flux on diagenetic reaction balances. J Mar Res 52:259-295

Alongi DM (1994) Zonation and seasonality of benthic primary production and community respiration in tropical mangrove forests. Oecologia 98:320-327

Alongi DM (1996) The dynamics of benthic nutrient pools and fluxes in tropical mangrove forests. J Mar Res 54:123-148

Alongi DM (1997) Coastal ecosystem processes. CRC Press, Boca Raton

Alongi DM, Sasekumar A (1992) Benthic communities. In: Robertson AI, Alongi DM (eds) Tropical mangrove ecosystems. Am Geophys Union, Washington, DC, p 137-171

Alongi DM, Sasekumar A, Tirendi F, Dixon P (1998) The influence of stand age on benthic decomposition and recycling of organic matter in managed mangrove forests of Malaysia. J Exp Mar Biol Ecol 225:197-218

Andersen FØ, Helder W (1987) Comparison of oxygen microgradients oxygen flux rates and electron transport system activity in coastal sediments. Mar Ecol Prog Ser 37: 259-264

Andersen FØ, Kristensen E (1988) Oxygen microgradients in the rhizosphere of the mangrove Avicennia marina (Forsk.) Vierh. Mar Ecol Prog Ser 44:201-204

Archer D, Devol A (1992) Benthic oxygen fluxes on the Washington shelf and slope: a comparison of in situ microelectrode and chamber flux measurements. Limnol Oceanogr 37:614-629

Armstrong FA, Stearns CR, Strickland JD (1967) The measurement of upwelling and subsequent biological processes by means of the Technicon Autoanalyzer and associated equipment. Deep-Sea Res 14:381-389

Banta GT, Holmer M, Jensen MH, Kristensen E (1999) Effects of two polychaete worms, Nereis diversicolor and Areni- cola marina, on aerobic and anaerobic decomposition in a sandy marine sediment. Aquat Microb Ecol 19:189-204

Benner R, Hodson RE (1985) Microbial degradation of the leachable and lignocellulosic components of leaves and wood from Rhizophora mangle in a tropical mangrove swamp. Mar Ecol Prog Ser 23:221-230

Benner R, Peele ER, Hodson RE (1986) Microbial uitilization of dissolved organic matter from leaves of the red mangrove, Rhizophora mangle, in the Fresh Creek estuary, Bahamas. Estuar Coast Shelf Sci 23:607-619

Boto KG, Wellington JT (1983) Phophorus and nitrogen nutritional status of a northern Australian mangrove forest. Mar Ecol Prog Ser 11:63-69

Boto KG, Alongi DM, Nott ALJ (1989) Dissolved organic carbon-bacteria interactions at sediment-water interface in a tropical mangrove system. Mar Ecol Prog Ser 51:243-251

Bower CE, Holm-Hansen T (1980) A salicylate-hypochlorite method for determining ammonia in seawater. Can J Fish Aquat Sci 37:794-798

Burdige DJ (1991) The kinetics of organic matter mineralization in anoxic marine sediments. J Mar Res 49:727-761

Canfield DE, Jørgensen BB, Fossing H, Glud R, Gundersen J, Ramsing NB, Thamdrup B, Hansen JW, Nielsen LP, Hall POJ (1993) Pathways of organic carbon oxidation in three continental margin sediments. Mar Geol 113:27-40

Canuel EA, Martens CS (1996) Reactivity of recently deposited organic matter: degradation of lipid compounds near the sediment-water interface. Geochim Cosmochim Acta 60:1793-1806

Chansang H, Poovachiranon S (1990) The fate of mangrove litter in a mangrove forest on Ko Yao Yai, southern Thailand. Phuket Mar Biol Cent Res Bull 54:33-46

Duke NC (1992) Mangrove floristics and biogeography. In: Robertson AI, Alongi DM (eds) Tropical mangrove ecosystems. Am Geophys Union, Washington, DC, p 63-100

Fenchel T, Blackburn TH (1979) Bacteria and mineral cycling. Academic Press, London

Fossing H (1995) ${ }^{35}$ S-radiolabeling to probe biogeochemical cycling of sulfur. In: Vairavamurthy MA, Schoonen MAA (eds) Geochemical transformations of sedimentary sulfur, Vol 612. American Chemical Society, Washington, DC, p 348-364

Fossing H, Jørgensen BB (1989) Measurement of bacterial sulfate-reduction in sediments: evaluation of a single-step chromium reduction method. Biogeochemistry 8:205-222

Froelich PN, Klinkhammer GP, Bender ML, Luedtke ML, Heath GR, Cullen D, Dauphin P, Hammond D, Hartman B, Maynard V (1979) Early oxidation of organic matter in pelagic sediments of the eastern equatorial Atlantic: suboxic diagenesis. Geochim Cosmochim Acta 43:1075-1090

Hall POJ, Aller RC (1992) Rapid,small-volume flow injection analysis for $\mathrm{SCO}_{2}$ and $\mathrm{NH}_{4}^{+}$in marine and freshwaters. Limnol Oceanogr 37:1113-1118

Hammond DE, McManus J, Berelson WM, Kilgore TE, Pope RH (1996) Early diagenesis of organic material in equatorial Pacific sediments: stoichiometry and kinetics. DeepSea Res II 43:1365-1412

Henrichs SM, Reeburgh WS (1987) Anaerobic mineralization of marine sediment organic matter: rates and the role of anaerobic processes in the oceanic carbon economy. Geomicrobiol J 5:191-237

Hines ME, Lyons WM (1982) Biogeochemistry of nearshore Bermuda sediments. I. Sulfate reduction rate and nutrient generation. Mar Ecol Prog Ser 8:87-94

Holmer M, Andersen FØ, Holmboe N, Kristensen E, Thongtham N (1999) Transformation and exchange processes in the Bangrong mangrove forest-seagrass bed system, Thailand. Seasonal and spatial variations in benthic 
metabolism and sulfur biogeochemistry. Aquat Microb Ecol 20:203-212

Howarth RR (1993) Microbial processes in salt-marsh sediments. In: Ford TE (ed) Aquatic microbiology: an ecological approach. Blackwell, Boston

Huettel M, Gust G (1992) Solute release mechanisms from confined sediment cores in stirred benthic chambers and flume flows. Mar Ecol Prog Ser 82:187-197

Iizumi H (1986) Soil nutrient dynamics. In: Cragg S, Polunin N (eds) Workshop on mangrove ecosystem dynamics. UNDP/UNESCO Regional Project, New Delhi, p 171-180

Jørgensen BB (1978) A comparison of methods for the quantification of bacterial sulfate reduction in coastal marine sediments. Geomicrobiol J 1:11-27

Jørgensen BB (1983) Processes at the sediment-water interface. In: Bolin B, Cook RB (eds) The major biogeochemical cycles and their interactions. SCOPE 21, Stockholm, p 477-509

King GM, Garey MA (1999) Ferric iron reduction by bacteria associated with the roots of freshwater and marine macrophytes. Appl Environ Microbiol 65:4393-4398

Kostka JE, Luther GW (1994) Partitioning and speciation of solid phase iron in saltmarsh sediments. Geochim Cosmochim Acta 58:1701-1710

Kostka JE, Luther GW (1995) Seasonal cycling of Fe in saltmarsh sediments. Biogeochemistry 29:159-181

Kristensen E (1990) Characterization of biogenic organic matter by stepwise thermogravimetry (STG). Biogeochemistry 9:135-159

Kristensen E, Andersen FØ (1987) Determination of organic carbon in marine sediments: comparison of two CHN-analyzer methods. J Exp Mar Biol Ecol 109:15-23

Kristensen E, Hansen K (1995) Decay of plant detritus in organic-poor marine sediment: production rates and stoichiometry of dissolved C and N compounds. J Mar Res 53: 675-702

Kristensen E, Pilgaard R (2000) The role of fecal pellet deposition by leaf-eating sesarmid crabs on mineralization processes in a mangrove sediment (Phuket, Thailand). In: Aller JY (ed) Organism-sediment interactions. University of South Carolina Press, Columbia (in press)

Kristensen E, Devol AH, Ahmed SI, Saleem M (1992) Preliminary study of benthic metabolism and sulfate reduction in a mangrove swamp of the Indus Delta, Pakistan. Mar Ecol Prog Ser 90:287-297

Kristensen E, King GM, Banta GT, Holmer M, Jensen MH, Hansen K, Bussarawit N (1994) Acetate turnover, sulfate reduction and carbon metabolism in sediments of the Ao Nam Bor mangrove, Phuket, Thailand. Mar Ecol Prog Ser 109:245-255

Kristensen E, Jensen MH, Banta GT, Hansen K, Holmer M, King GM (1998) Aspects of nitrogen cycling in sediments of a southeast Asian mangrove forest. Aquat Microb Ecol 15:165-175

Kristensen E, Devol AH, Hartnett HE (1999) Carbon and nitrogen diagenesis in sediments on the continental slope of the eastern tropical and temperate North Pacific. Cont Shelf Res 19:1331-1351

Lovley DR, Phillips EJP (1987) Rapid assay for microbially reducible ferric iron in aquatic sediments. Appl Environ Microbiol 53:1536-1540

Luther GW, Shellenberger PA, Brendel PJ (1996) Dissolved

Editorial responsibility: Gary King,

Walpole, Maine, USA organic Fe(III) and Fe(II) complexes in salt marsh porewaters. Geochim Cosmochim Acta 60:951-960

Mackin JE, Swider KT (1989) Organic matter decomposition pathways and oxygen consumption in coastal marine sediments. J Mar Res 47:681-716

Magenheimer JF, Moore TR, Chmura GL, Daoust RJ (1996) Methane and carbon dioxide flux from a macrotial salt marsh, Bay of Fundy, New Brunswick. Estuaries 19: 139-145

Middelburg JJ, Nieuwenhuize J, Slim FJ, Ohowa B (1996) Sediment biogeochemistry in an East African mangrove forest (Gazi Bay, Kenya). Biogeochemistry 34:133-155

Nedwell DB, Blackburn TH, Wiebe WJ (1994) Dynamic nature of the turnover of organic carbon, nitrogen and sulphur in the sediments of a Jamaican mangrove forest. Mar Ecol Prog Ser 110:223-231

Neilson MJ, Richards GN (1989) Chemical composition of degrading mangrove leaf litter and changes produced after consumption by mangrove crab Neosarmation smithi (Crustacea: Decapoda: Sesarmidae). J Chem Ecol 15: 1267-1283

Parsons TR, Maita Y, Lalli CM (1984) A manual of chemical and biological methods for seawater analysis. Pergamon, Oxford

Ridd PV (1996) Flow through animal burrows in mangrove creeks. Estuar Coast Shelf Sci 43:617-625

Rivera-Monroy VH, Twilley RR (1996) The relative role of denitrification and immobilization in the fate of inorganic nitrogen in mangrove sediments (Terminos Lagoon, Mexico). Limnol Oceanogr 41:284-296

Robertson AI (1986) Leaf-burying crabs: their influence on energy flow and export from mixed mangrove forests (Rhizophora spp.) in northeastern Australia. J Exp Mar Biol Ecol 102:237-248

Roden EE, Wetzel RG (1996) Organic carbon oxidation and suppression of methane production by microbial Fe(III) oxide reduction in vegetated and unvegetated freshwater wetland sediments. Limnol Oceanogr 41:1733-1748

Slomp CP, Malschaert JFP, Lohse L, van Raaphorst W (1997) Iron and manganese cycling in different sedimentary environments on the North Sea continental margin. Continent Shelf Res 17:1083-1117

Stanley SO, Boto KG, Alongi DM, Gillan FT (1987) Composition and bacterial utilization of free amino acids in tropical mangrove sediments. Mar Chem 22:13-30

Stookey LL (1970) Ferrozine-a new spectrophotometric reagent for iron. Anal Chem 42:779-781

Sun M, Aller RC, Lee C (1991) Early diagenesis of chlorophyll-a in Long Island Sound sediments: a measure of carbon flux and particle reworking. J Mar Res 49:379-401

Thamdrup B (2000) Microbial manganese and iron reduction in aquatic sediments. Adv Microb Ecol 16:41-84

Thamdrup B, Fossing H, Jørgensen BB (1994) Manganese, iron, and sulfur cycling in a coastal marine sediment, Aarhus Bay, Denmark. Geochim Cosmochim Acta 58:5115-5130

Twilley RR, Lugo AE, Patterson-Zucca C (1986) Litter production and turnover in basin mangrove forests in Southwest Florida. Ecology 67:670-683

Wafar S, Untawale AG, Wafar M (1997) Litter fall and energy flux in a mangrove ecosystem. Estuar Coast Shelf Sci 44:111-124

Submitted: December 10, 1999; Accepted: July 19, 2000

Proofs received from author(s): August 25, 2000 